Review

\title{
Iron Sulfide Materials: Catalysts for Electrochemical Hydrogen Evolution
}

\author{
Dominikus Heift \\ Department of Chemistry, Durham University, Lower Mount Joy, South Rd, Durham DH1 3LE, UK; \\ dominikus.heift@durham.ac.uk
}

Received: 25 May 2019; Accepted: 14 June 2019; Published: 19 June 2019

\begin{abstract}
The chemical challenge of economically splitting water into molecular hydrogen and oxygen requires continuous development of more efficient, less-toxic, and cheaper catalyst materials. This review article highlights the potential of iron sulfide-based nanomaterials as electrocatalysts for water-splitting and predominantly as catalysts for the hydrogen evolution reaction (HER). Besides new synthetic techniques leading to phase-pure iron sulfide nano objects and thin-films, the article reviews three new material classes: (a) $\mathrm{FeS}_{2}-\mathrm{TiO}_{2}$ hybrid structures; (b) iron sulfide-2D carbon support composites; and (c) metal-doped (e.g., cobalt and nickel) iron sulfide materials. In recent years, immense progress has been made in the development of these materials, which exhibit enormous potential as hydrogen evolution catalysts and may represent a genuine alternative to more traditional, noble metal-based catalysts. First developments in this comparably new research area are summarized in this article and discussed together with theoretical studies on hydrogen evolution reactions involving iron sulfide electrocatalysts.
\end{abstract}

Keywords: iron sulfide; nanomaterials; electrocatalysts; hydrogen evolution; water-splitting

\section{Introduction}

On our planet, atomic hydrogen $\mathrm{H}$ predominantly exists chemically bonded in natural molecules and products such as water, petroleum, and coal. In contrast, molecular hydrogen $\mathrm{H}_{2}$ does not occur naturally in large amounts on Earth and is only produced by certain microorganisms [1] in small quantities, which escape Earth's gravity into the atmosphere due to the low molecular weight. Despite the low natural abundance of hydrogen gas $\mathrm{H}_{2}$ on Earth, it has indisputably been identified as a major energy carrier of the future as $\mathrm{H}_{2}$ has the highest gravimetric energy density of all known substances (lower heating value of $\sim 120 \mathrm{~kJ} / \mathrm{g}$ ) [2], is non-poisonous and, most importantly, hydrogen gas can be derived from water. Using water, which is often termed as "the renewable fuel", as a sustainable and abundant energy source has been a dream of novelists and scientists for a long time [3] and for several decades researchers of various disciplines have been working on energetically favorable and cheap processes to catalyze the decomposition reaction of water into clean molecular hydrogen and oxygen. The "Steam-Iron" process $\left(3 \mathrm{Fe}+4 \mathrm{H}_{2} \mathrm{O} \rightarrow \mathrm{Fe}_{3} \mathrm{O}_{4}+4 \mathrm{H}_{2}\right)$ is one of the oldest commercial methods for producing hydrogen from water and was practiced at the beginning of the 20th century to generate small quantities of pure hydrogen [4]. Remarkably, a recent study has found that traces of $\mathrm{HS}^{-}$in the process forming $\mathrm{FeS}$ on the iron catalyst surface, can significantly enhance the hydrogen evolution reaction (HER) [5].

In general, the water-splitting process consists of two half-reactions: the water oxidation (oxygen evolution reaction, OER) and the water reduction (hydrogen evolution reaction, HER). Regardless of the $\mathrm{pH}$ of the solution, the voltage required for the splitting of $\mathrm{H}_{2} \mathrm{O}$ into $\mathrm{H}_{2}$ and $\frac{1}{2} \mathrm{O}_{2}$ is $1.23 \mathrm{~V}$ $\left(25^{\circ} \mathrm{C}, 1 \mathrm{~atm}\right)$. However, in reality one must apply voltages higher than the theoretical value of 1.23 $\mathrm{V}$ to achieve electrochemical water-splitting. This excess potential (overpotential, $\eta$ ) is required to 
overcome intrinsic activation barriers at the electrodes and solution resistance [6]. Consequently, an energy-efficient water-splitting system should have a low $\eta$ value and much effort is made towards developing powerful electrode materials with low overpotential.

A key step in hydrogen gas formation from an aqueous solution is the reduction of $\mathrm{H}^{+}$on a catalyst's surface with an electron to form surface-adsorbed hydrogen. Subsequently, for the catalyst to be efficient, fast liberation of the hydrogen gas from the catalyst surface is essential. In this context, the free energy of hydrogen adsorption, $\Delta \mathrm{G}_{\mathrm{H}}$, is a significant measure for the catalytic activity of a hydrogen-evolving electrocatalyst [7]. Ideally, for a catalyst this energy (which must be invested to release molecular hydrogen from the catalyst surface) should be nearly zero. Such ideal $\Delta G_{H}$ values are observed for elemental platinum and consequently, platinum-based materials have been found to be the most efficient hydrogen evolution catalysts [8]. Due to the high cost and low natural abundance of platinum in the Earth crust $\left(3.7 \times 10^{-6 \%}\right)$, which is orders of magnitudes lower than that of non-precious metals such as $\mathrm{Ni}(0.0089 \%)$ or $\mathrm{Fe}(6.8 \%)$, much effort is devoted to find alternative, noble metal-free hydrogen evolution catalysts [6].

In recent years, significant progress has been made in developing innovative, less-expensive catalysts for HER whereby especially new nanomaterial-based catalysts exhibit remarkable HER efficiencies [9]. Inspired by natural photosynthesis, in which water and carbon dioxide are converted into molecular oxygen and carbohydrates, a significant research focus has been on the development of artificial photocatalysts, which could facilitate the light-driven generation of hydrogen from water. Significantly, also the biochemical processes taking place during photosynthesis in photosystems I and II are based on the redox chemistry of non-noble metals such as manganese and calcium or the Rieske iron sulfur protein, which contains a [2Fe-2S] cluster [9]. Other prominent examples from nature are hydrogenases, a group of metalloenzymes that catalyze the oxidation of $\mathrm{H}_{2}$ into protons and electrons as well as the reverse reaction, the generation of $\mathrm{H}_{2}$ [10]. Inspired by these enzymes, researchers also work on the development of molecular iron sulfur compounds to employ them as "artificial enzymes" in catalysis [11]. Even though significant progress is made in this research area, often such molecular species are prone to decomposition in solution.

Thus, in line with these systems, there has been a growing interest in the biosynthesis of related nanomaterials and the most extensive research has been focused on metal sulfides. For example, bacteria, fungi, or other microorganisms can convert sulfate into reduced sulfide species, which react with metal cations to generate metal sulfide structures [12]. However, typically during these processes it is difficult to control the purity and shape of the forming nanostructure.

Therefore, mimicking such biological processes and developing more sophisticated artificial synthetic procedures for transition metal oxide or sulfide nanostructures has been the aim of many research studies. In this context, in particular the development of transition metal dichalcogenide (TMDC) materials ( $\mathrm{MX}_{2}, \mathrm{M}$ : e.g., $\mathrm{Mo}, \mathrm{Co}, \mathrm{Fe}, \mathrm{Ni} ; \mathrm{X}=\mathrm{O}, \mathrm{S}, \mathrm{Se}, \mathrm{Te}$ ) has attracted the attention of many research groups. Due to superior electrochemical performance, high stability in acid conditions and low fabrication costs TMDC materials exhibit excellent properties as water-splitting catalysts [13-17]. The performance of TMDC catalyst materials heavily depends on their electronic structure and to reach superior catalytic properties it is essential to pull down the Fermi level or decrease the band gap of the structures. Typical strategies to do this include doping of the TMDC lattice with impurity atoms or compounds and intentional creation of structural defects. Theoretical studies show that the performance of TMDC-based HER electrocatalysts severely depends on the hydrogen adsorption energy and that $\Delta \mathrm{G}_{\mathrm{H}}$ is an indicator to predict the catalytic activity based on the materials' electronic structure [18].

Due to the high natural abundance, very low cost and low toxicity of iron and sulfur, the TMDC $\mathrm{FeS}_{2}$ and other iron sulfide structures are very desirable catalyst materials. However, while iron sulfide structures have been thoroughly studied and have been shown to be good semiconductors for photovoltaic devices [14,19,20], iron sulfide-based catalysts for HER are much less developed. Compared to benchmark precious metal-free HER catalysts such as $\mathrm{MoS}_{2}$ [21] or transition metal 
phosphides [22], typically iron sulfide catalysts are less efficient and prone to corrosion. For example, a reactivity study on $\mathrm{Fe}_{x} \mathrm{~S}_{y}$ films shows their tendency to transform to oxidation products [23]. Thus, regarding the obvious benefits of iron sulfide materials there is an urgent need to develop more efficient and stable iron sulfide catalyst materials for HER. It is to be hoped that the stability of new iron sulfide catalysts can be increased through rational design of nanostructured materials and surfaces.

The chemistry of iron sulfides is very complex, with the formation of diverse iron sulfide phases such as $\mathrm{FeS}, \mathrm{Fe}_{1-x} \mathrm{~S}, \mathrm{FeS}_{2}, \mathrm{Fe}_{3} \mathrm{~S}_{4}$, etc. being very sensitive to factors such as temperature, pressure or $\mathrm{pH}$, and is still not fully understood [24]. The recent discovery of an entirely new nanoparticulate iron sulfide phase, $\mathrm{FeS}_{\text {nano, }}$, illustrates the complexity of the field. $\mathrm{FeS}_{\text {nano }}$ contains tetrahedral iron sites and is balanced by monosulfide and polysulfide sulfur species, which together dramatically affect the stability and enhance the reactivity of $\mathrm{FeS}_{\text {nano }}$ making it highly desirable as a potential catalyst material [25]. Moreover, $\mathrm{FeS}_{\text {nano }}$ has been identified as a crucial precursor for the iron sulfide material mackinawite ( $\mathrm{FeS})$, a metastable intermediate structure, which itself can be a precursor to the formation of the more stable $\mathrm{Fe}_{3} \mathrm{~S}_{4}$ and $\mathrm{FeS}_{2}$ phases. Due to the small size of constituent particles and highly disordered domains, mackinawite nanostructures can be highly reactive and therefore useful for the design of new catalyst materials [26].

In general, the fabrication of effective iron sulfide-based catalysts requires the synthesis of materials exhibiting defined iron sulfur ratios (phase purity) and well-defined shapes (spheres, cubes, wires, etc.) [27]. Regarding catalysis, both phase purity and morphology are of major significance for controlling and improving the performance of the catalyst material. The chemistry and syntheses of iron sulfide nanostructures [28] and thin-films [29,30], with their enormous potential for photovoltaic devices [31,32] and electrode materials [33] have been extensively reviewed in the literature. Therefore, the following article does not provide a comprehensive collection of research developments in this area, but rather highlights the latest milestones to spark the scientific communities' interest for iron sulfide electrocatalysts. While the main focus is on iron sulfide-catalyzed HER, some examples of OER and iron sulfide-catalyzed overall water-splitting processes will be discussed. The first part of the article highlights new synthetic approaches to various iron sulfide nanostructures (e.g., $\mathrm{FeS}_{2}, \mathrm{Fe}_{3} \mathrm{~S}_{4}$, etc.) and reflects how much their electrochemical activity depends on the structure and phase purity of the materials. In the next section, the concept of iron disulfide-doped titanium dioxide structures and the impact of $\mathrm{FeS}_{2}$-doping on the photocatalytic performance of $\mathrm{TiO}_{2}$ will be discussed. Furthermore, the review summarizes recent milestones in the area of iron sulfide-2D carbon nanomaterial hybrid HER catalysts and concludes with a few examples of metal-doped iron sulfide electrocatalysts. Appendix A of this review contains Table A1 of all discussed iron sulfide materials, summarizing experimental procedures and HER performance data.

\section{Iron Sulfide Phases as Electrocatalysts}

\subsection{Iron Monosulfide, FeS}

Recently Zhang and co-workers discovered the potential of iron monosulfide $\mathrm{FeS}$ as a low-cost pre-electrocatalyst for water-splitting [34]. Through treatment of an iron foam (IF) with thiourea under hydrothermal conditions they obtained FeS nanosheets, which grew on the iron foam. This material FeS@IF alone (just like FeS or IF) shows only very poor catalytic activity for HER. (In this article X@Y denotes material composites or core-shell particles consisting of two different phases $\mathrm{X}$ and $\mathrm{Y}$, whereby $\mathrm{X}$ is covering the inner phase $\mathrm{Y}$ ). Once "electrochemically activated" at the beginning of the electrolysis process, Fe@Fe oxysulfide nanoparticles are generated in situ on the FeS nanosheets. Remarkably, this $\mathrm{Fe} @ \mathrm{FeO}_{x} \mathrm{~S}_{y}$ material exhibits a high activity to catalyze both HER and OER simultaneously (Figure 1). At small current densities, the water-splitting output of $\mathrm{Fe}_{\mathrm{O}} \mathrm{FeO}_{x} \mathrm{~S}_{y}$ is comparable with that of the benchmark system $\mathrm{Pt} / \mathrm{C}-\mathrm{IrO}_{2}$ and at larger current densities it exhibits even better outputs.

Air-stable FeS nanoparticles dispersed on Nafion films, invented by Giraud, Tard and co-workers [35,36], have attracted much attention for HER reactors. FeS nanoparticles are prepared 
by solvothermal decomposition of the single-source precursor $\mathrm{Fe}_{2} \mathrm{~S}_{2}(\mathrm{CO})_{6}$ at $230{ }^{\circ} \mathrm{C}$ in the presence of octylamine. Subsequently, vitreous carbon rotating disk electrodes are coated with the catalyst ink, which is prepared by dispersion of the FeS nanoparticles in Nafion. The system achieves HER electrocatalysis of neutral water at room temperature with a mild over potential, and no structural decomposition of the catalyst material or decrease in activity is observed for at least six days. A decrease in overpotential occurs during the first $24 \mathrm{~h}$ indicating a rise in hydrogen evolution activity, which is likely due to some modifications of the catalyst surface. Remarkably, with no particular storage care these electrodes were found to be stable for electrochemical studies for more than 6 months.
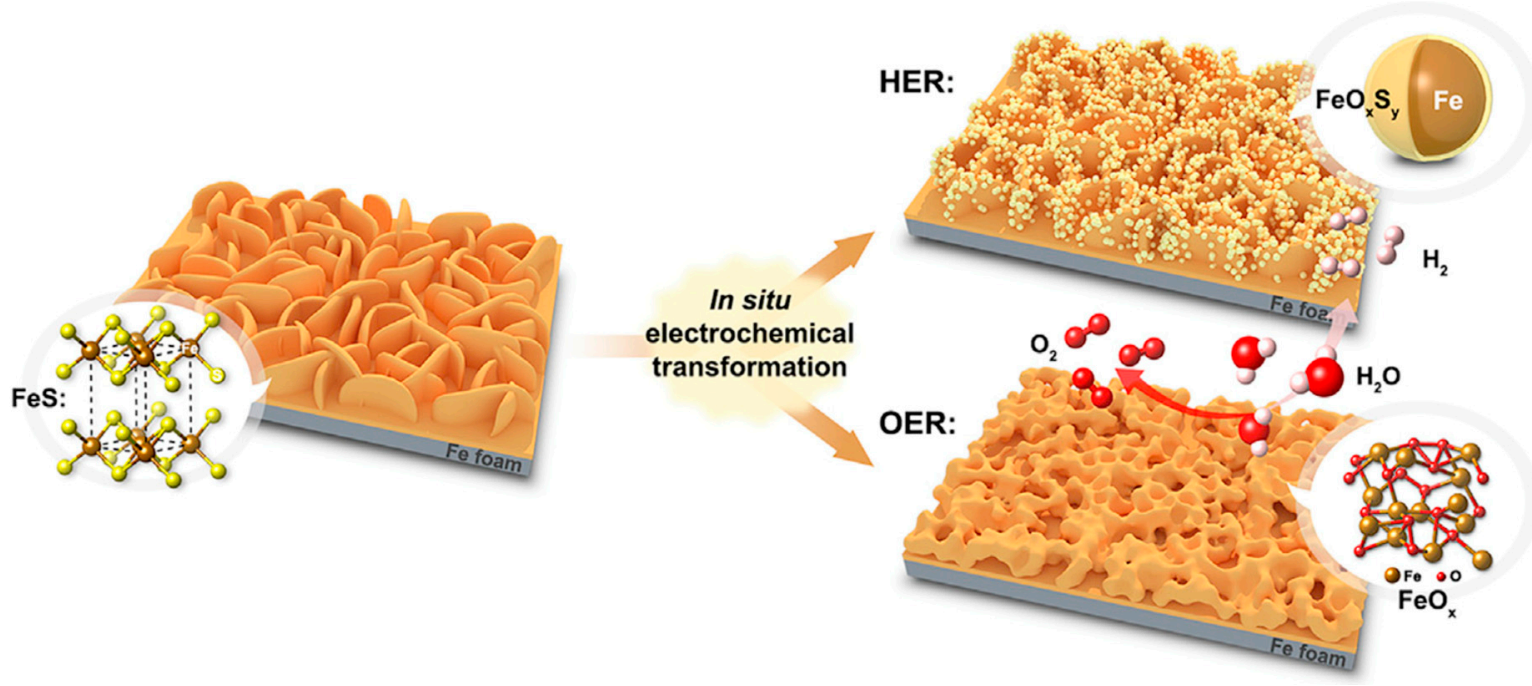

Figure 1. FeS nanosheets grown on iron foam act as pre-catalyst for generation of $\mathrm{Fe} @ \mathrm{FeO} x \mathrm{~S}_{y}$, which is a highly active electrocatalyst and splits water simultaneously into molecular hydrogen and oxygen. Reprinted with permission from reference [34].

\subsection{Iron Disulfide, $\mathrm{FeS}_{2}$}

Iron disulfide (pyrite, $\mathrm{FeS}_{2}$ ) is the most prominent phase among the iron sulfides. Due to its unique properties (suitable band gap of $\mathrm{E}=0.95 \mathrm{eV}$ and extremely high absorption coefficient $\alpha>105 \mathrm{~cm}^{-1}$ ) it has been extensively investigated as a photovoltaic semiconductor [19] and high-performance electrode material [37]. The physiochemical properties of $\mathrm{FeS}_{2}$ depend critically on its purity and shape; therefore, much effort has been devoted to controlling these factors. Various synthetic procedures for pyrite and applications of pyrite materials have been comprehensively reviewed in the literature $[19,28,38,39]$. These works show that a major challenge remains the access to single crystalline, high-purity $\mathrm{FeS}_{2}$ materials with a precise stoichiometric ratio, as $\mathrm{Fe}_{1-x} \mathrm{~S}$ impurities are commonly observed in $\mathrm{FeS}_{2}$ structures. Structural defects coming along with these impurities ( $\mathrm{S}$ vacancies and interstitial atoms) significantly diminish the photoelectric conversion efficiency of $\mathrm{FeS}_{2}$-based devices [28].

\subsection{1. $\mathrm{FeS}_{2}$ Wires and Discs}

Besides phase purity also the shape of $\mathrm{FeS}_{2}$ catalysts effects their performance and Ren, Leonard and co-workers demonstrate in a study how strong the HER activity indeed depends on the morphology of the nanomaterials. Following a hot-injection procedure and starting from $\mathrm{FeI}_{2}$, elemental sulfur and octadecylamine (which acts as reducing and capping agent), they describe the synthesis of low-dimensional, hyperthin $1 \mathrm{D} \mathrm{FeS}_{2}$ wires, and $2 \mathrm{D} \mathrm{FeS}_{2}$ discs. Notably, both $\mathrm{FeS}_{2}$ nanomaterials can be obtained following the same synthetic pathway by only changing the ratio of iron precursor and sulfur $[40,41]$ (Figure 2A). The authors determined the exchange current density (a measure of kinetics for HER) of the $1 \mathrm{D} \mathrm{FeS}_{2}$ wires and 2D FeS 2 discs and remarkably, 2D FeS 2 discs clearly exhibit the higher electrocatalytic activity for HER compared to $1 \mathrm{D} \mathrm{FeS}_{2}$ wires and other tested $\mathrm{FeS}_{2}$ morphologies 
(Figure 2B). In fact, the electrochemical performance of the investigated $2 \mathrm{D} \mathrm{FeS}_{2}$ discs is comparable to that of platinum in neutral $\mathrm{pH}$ conditions [40].

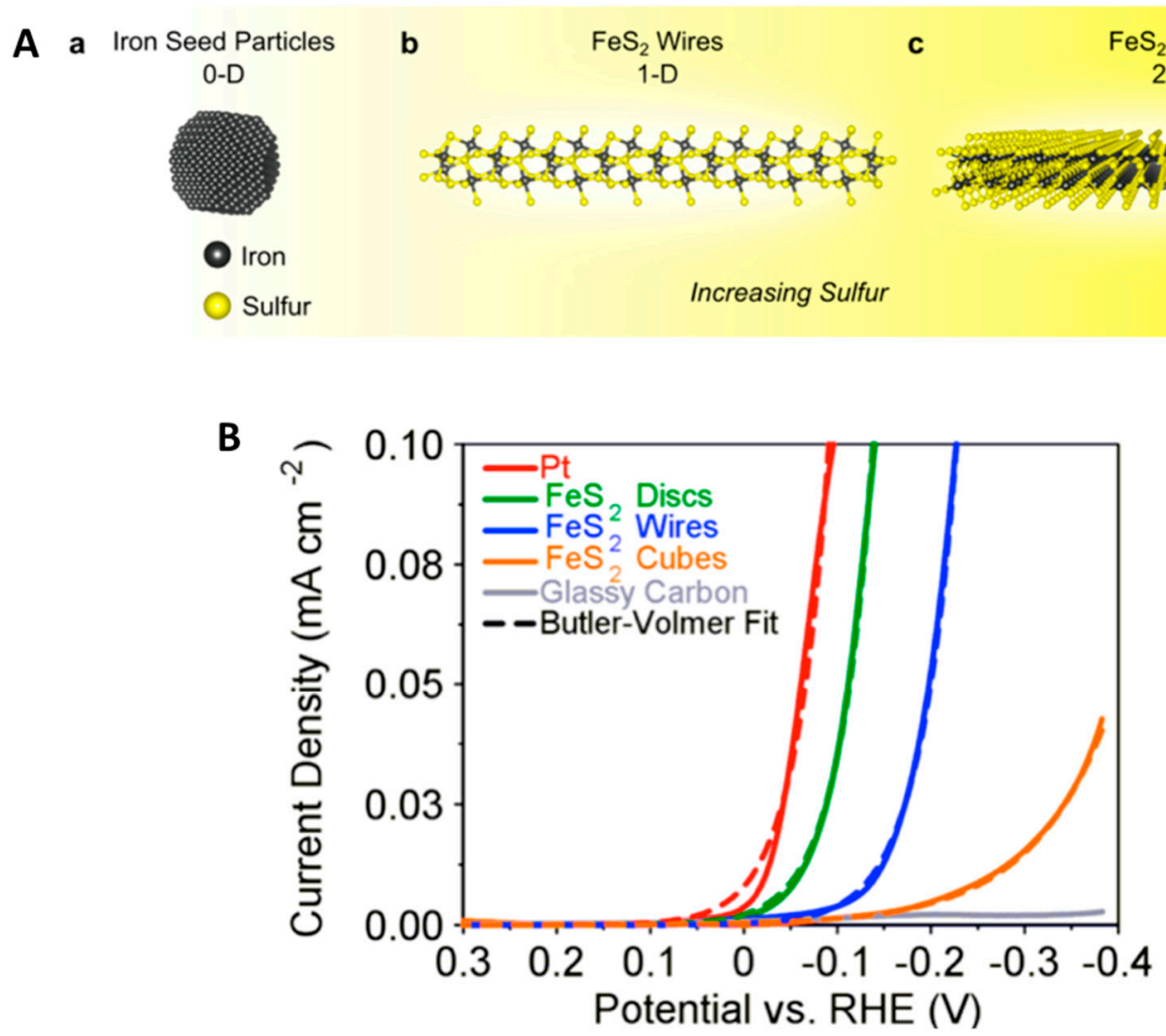

Figure 2. (A) Schematic representations of $1 \mathrm{D}$ and $2 \mathrm{D} \mathrm{FeS}_{2}$ structure formation. a: Fe nanoparticles (formed in the absence of sulfur), b: $\mathrm{FeS}_{2}$ wires (formed in a 1:6 Fe/S ratio reaction) and c: $\mathrm{FeS}_{2}$ discs (formed in a 1:24 Fe/S ratio). (B) Experimental linear sweep voltammograms at $1 \mathrm{mV} / \mathrm{s}$ for different $\mathrm{FeS}_{2}$ morphologies (solid lines) and the corresponding best-fit single-electron Butler-Volmer equations (dashed lines). Reprinted with permission from reference [40].

\subsubsection{Mesoporous $\mathrm{FeS}_{2}$ Nanoparticles}

The activity of any heterogeneous catalyst depends on its surface area, which should be as large as possible to reach maximum catalytic effects. In this context, mesoporous materials (materials containing pores with diameters between $2 \mathrm{~nm}$ and $50 \mathrm{~nm}$ ) [42] have reached much attention. Suib and co-workers succeeded in synthesizing mesoporous $\mathrm{FeS}_{2}$ nanoparticles by sulfidation of iron oxide nanoparticles. In a first reaction step $\mathrm{Fe}_{2} \mathrm{O}_{3}$ nanoparticles are produced via an inverse micelle sol-gel method and then heated to $150^{\circ} \mathrm{C}$ to yield a mesoporous $\mathrm{Fe}_{2} \mathrm{O}_{3}$ structure. Subsequently, this oxide substrate is converted with hydrogen sulfide and elemental sulfur into mesoporous $\mathrm{FeS}_{2}$ nanoparticles [43]. Theoretical calculations indicate that the exposed (201) facets of this mesoporous pyrite material are key for its excellent HER activity at $\mathrm{pH} 13$ (low over potential of $96 \mathrm{mV}\left(10 \mathrm{~mA} \mathrm{~cm}{ }^{-2}\right)$, Tafel slope of $\left.78 \mathrm{mV} \mathrm{dec}^{-1}\right)$.

\subsection{3. $\mathrm{FeS}_{2} / \mathrm{C}$ Electrode Coating}

While several studies found $\mathrm{FeS}_{2}$ electrocatalysts with significant HER activity, reports on $\mathrm{FeS}_{2}$ materials for OER or overall water-splitting are very limited. Li, Wang and co-workers published a rare example and demonstrated $\mathrm{FeS}_{2} / \mathrm{C}$ nanoparticles as efficient bifunctional catalysts for overall water-splitting [44]. These $\mathrm{FeS}_{2} / \mathrm{C}$ nanoparticles were prepared by suspending $\mathrm{FeS}_{2}$ nanoparticles (obtained in a hydrothermal process from $\mathrm{FeCl}_{3} \cdot\left(\mathrm{H}_{2} \mathrm{O}\right)_{6}$ and diethy-dithio-carbamate trihydrate) and carbon powder in a water/ethanol mixture containing $5 \%$ Nafion. Immobilized on nickel foam, 
this $\mathrm{FeS}_{2} / \mathrm{C}$ electrode material can serve as electrocatalyst towards both OER and HER. For OER, excellent activity was obtained $\left(240 \mathrm{mV}\right.$ overpotential at $\left.10 \mathrm{~mA} \mathrm{~cm}{ }^{-2}\right)$, which is lower than that of $\mathrm{IrO}_{2}$ ( 310-320 mV [45,46]). Similarly, and with nearly no activity loss after 1000 cycles, $202 \mathrm{mV}$ at $10 \mathrm{~mA}$ $\mathrm{cm}^{-2}$ overpotential was measured for the hydrogen evolution. An overall water-splitting process with this $\mathrm{FeS}_{2} / \mathrm{C}$ electrode is achieved with $1.72 \mathrm{~V}$ at $10 \mathrm{~mA} \mathrm{~cm}^{-2}$.

\subsection{4. $\mathrm{FeS}_{2}$ Thin-Films}

Chi and Liu developed a combined physical vapor deposition (PVD) and thermal vapor sulfurization technique to produce $\mathrm{FeS}_{2}$ thin-films. In this process, $\mathrm{Fe}_{3} \mathrm{~S}_{4}$ thin-films are deposited together with elemental sulfur in a tube furnace system and $\mathrm{Fe}_{3} \mathrm{~S}_{4}$ is sulfurized and converted into pure $\mathrm{FeS}_{2}$ thin-films without any crystal phase incorporation [47]. Such traditional vapor deposition methods (chemical vapor deposition (CVD) or PVD) for thin-film substrates generally have limitations in film purity, roughness, and process controllability. In contrast, a new powerful technique, Atomic Layer Deposition (ALD) facilitates access to high-quality and high-purity thin-film substrates [48]. ALD provides a layer-by-layer growth process of substrates enabling precise control of both film composition and thickness. In this way, Guo and Wang recently achieved the first ALD synthesis of $\mathrm{FeS}_{2}$ thin-films [49]. During the ALD process an iron amidinate precursor [iron-bis $\left(N, N^{\prime}\right.$-di-tert-butylacetamidinato)] is treated with a hydrogen sulfide plasma to generate well-crystallized, pyrite $\mathrm{FeS}_{2}$ thin-films (Figure 3). The so-produced pyrite (cubic lattice) $\mathrm{FeS}_{2}$ thin-films can contain traces of marcasite (orthorhombic $\mathrm{FeS}_{2}$ lattice). Noteworthy, this orthorhombic $\mathrm{FeS}_{2}$ structure has recently been reported by Hofmann and co-workers to enhance the photoresponse of cubic pyrite $\mathrm{FeS}_{2}$ films [50].

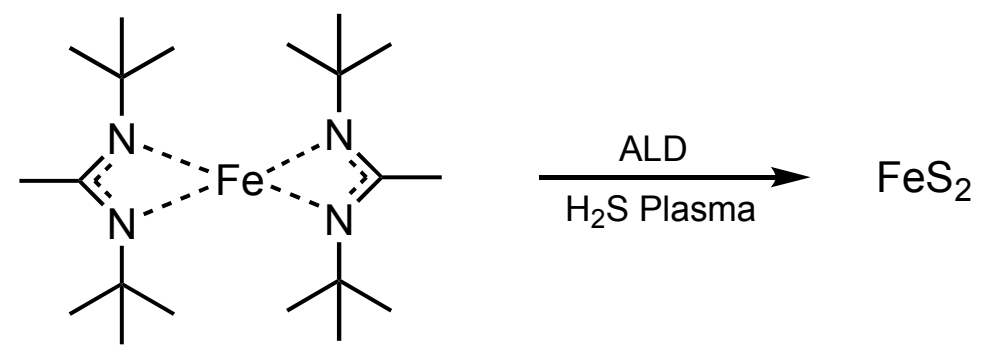

Figure 3. Pyrite $\mathrm{FeS}_{2}$ thin-film production by Atomic Layer Deposition (ALD) [49].

\subsubsection{Resistance of $\mathrm{FeS}_{2}$ Catalysts to Sulfide Poisoning}

Traditional HER electrocatalysts such as platinum materials or other transition metal structures are usually susceptible to poisons such as arsenide or sulfur resulting in a substantial decrease in catalytic activity [51]. To investigate the sulfide-resistance of $\mathrm{FeS}_{2}$ HER catalysts, the poisoning effect of sulfide on $\mathrm{FeS}_{2}$ surface was examined by Chua and Pumera by linear sweep voltammetry [52]. Remarkably, the authors found that $\mathrm{FeS}_{2}$ electrocatalysts are extremely resistant to sulfide poisoning. The degradation effect of additional sulfide species on the $\mathrm{FeS}_{2}$ surface is not as severe as observed for platinum-based catalyst materials and results only in a slight increment of overpotential.

\section{3. $p H$ Dependence of Iron Sulfide Electrocatalysts}

The performance of iron sulfide electrocatalysts does not only depend on the phase composition and morphology of the catalyst material, but also on the $\mathrm{pH}$ of the electrolyzed solution. Importantly, the $\mathrm{pH}$ range of a solution can change drastically during electrolysis processes. Since this effect is primarily observed directly at the electrodes on the catalyst surface, a locally high concentration of $\mathrm{H}^{+}$or $\mathrm{OH}^{-}$ions can chemically change the phase composition of a catalyst. As an example, Holt, de Leeuw and co-workers observed a $\mathrm{pH}$-dependent effect with greigite $\left(\mathrm{Fe}_{3} \mathrm{~S}_{4}\right)$ electrocatalysts [53]. During their studies on $\mathrm{Fe}_{3} \mathrm{~S}_{4}$-catalyzed HER they observed a large increase of the $\mathrm{pH}$ at the electrode 
surface from $\mathrm{pH} 7$ to $\mathrm{pH} 12 . \mathrm{Fe}_{3} \mathrm{~S}_{4}$ is thermodynamically unstable under these basic conditions, being transformed to goethite (iron hydroxide) [24]. Consequently, iron hydroxide covers the electrode surface and must be considered to be a catalytic species for the HER process. Similarly, Giraud, Tard and co-workers monitored the $\mathrm{pH}$ dependence of a $\mathrm{FeS}_{2}$-catalyzed hydrogen evolution process [54]. The $\mathrm{FeS}_{2}$ nanoparticles used in this process (synthesized from $\mathrm{FeCl}_{3}$ and thiourea in a polyol process) show remarkable robustness and stability at very broad $\mathrm{pH}$ range (0.3-13). During this electrochemical reaction, at lower $\mathrm{pH}$ values a $\mathrm{pH}$-dependent catalytic activity is observed, while above $\mathrm{pH} 5$ the catalytic performance appears to be $\mathrm{pH}$-independent. This observation indicates two entirely different electrochemical reaction mechanisms at low and high $\mathrm{pH}$ ranges, respectively.

\subsection{HER Activity of Iron Sulfides in Comparison}

Peron, Giraud, Tard, and co-workers carried out a detailed study to compare the performance of $\mathrm{FeS}_{2}, \mathrm{Fe}_{3} \mathrm{~S}_{4}$ and $\mathrm{Fe}_{9} \mathrm{~S}_{10}$ electrocatalysts for proton exchange membrane (PEM) electrolyzers [35,55]. Electrochemical experiments led to the conclusion that $\mathrm{FeS}_{2}$ is more active for HER than $\mathrm{Fe}_{3} \mathrm{~S}_{4}$, which itself is more active than $\mathrm{Fe}_{9} \mathrm{~S}_{10}$. It has been ascertained in other studies on sulfide materials that a high density of sulfur atoms at the material surface and in particular the presence of disulfide $\mathrm{S}_{2}{ }^{2-}$ moieties causes a high catalytic activity (see [55] and references cited therein). A higher density of $\mathrm{S}_{2}{ }^{2-}$ active sites in $\mathrm{FeS}_{2}$ compared to $\mathrm{Fe}_{3} \mathrm{~S}_{4}$ and $\mathrm{Fe}_{9} \mathrm{~S}_{10}$ becomes obvious from the different sulfur-iron ratios changing in the order $2\left(\mathrm{FeS}_{2}\right)>1.33\left(\mathrm{Fe}_{3} \mathrm{~S}_{4}\right)>1.11\left(\mathrm{Fe}_{9} \mathrm{~S}_{10}\right)$. Furthermore, in pyrite $\mathrm{FeS}_{2}$ the formal oxidation states of $\mathrm{Fe}^{+\mathrm{II}}$ and $\mathrm{S}^{-\mathrm{I}}$ as well as the structural motive $\mathrm{Fe}_{3}-\mathrm{S}-\mathrm{S}-\mathrm{Fe}_{3}$ (with $\mathrm{S}_{2}{ }^{2-}$ dumbbells connecting six iron centers) explain the high natural occurrence of $\mathrm{S}_{2}{ }^{2-}$ moieties in $\mathrm{FeS}_{2}$ [55]. The modest catalytic activity of $\mathrm{Fe}_{3} \mathrm{~S}_{4}$ is also the subject of a theoretical study by Roldan and de Leeuw. The authors show that $\mathrm{Fe}_{3} \mathrm{~S}_{4}$-catalyzed water dissociation is indeed thermodynamically unfavorable and molecular adsorption of water on the $\mathrm{Fe}_{3} \mathrm{~S}_{4}$ surface is occurring instead [56].

\section{3. $\mathrm{FeS}_{2}-\mathrm{TiO}_{2}$ Composite Materials}

Titanium dioxide is a powerful photocatalyst (high photoactivity, non-toxic, chemically stable and inexpensive); however, due to its rather large band gap (3.2 eV for anatase $\mathrm{TiO}_{2}$ [57]) it only responds to UV (ultraviolet) light. The decoration of $\mathrm{TiO}_{2}$ nanomaterials with transition metal photocatalysts is a promising approach to extend the absorption of $\mathrm{TiO}_{2}$ to the visible and even infrared regions of the electromagnetic spectrum [58]. A potential candidate for this application is $\mathrm{FeS}_{2}$, which exhibits a large optical absorption coefficient $\left(>105 \mathrm{~cm}^{-1}\right)$ and a narrow band gap of $0.95 \mathrm{eV}$ [59].

Lee and Kang followed this approach and verified that the loading of $\mathrm{FeS}_{2}$ nanoparticles on $\mathrm{TiO}_{2}$ enhances the production of hydrogen from methanol/water mixtures [60]. The authors performed cyclic voltammetric and UV-Vis spectrometric measurements and explain the superior photoactivity of $\mathrm{FeS}_{2} / \mathrm{TiO}_{2}$ hybrid catalysts compared to that of pure $\mathrm{TiO}_{2}$ with a smaller band gap of the former $(2.89 \mathrm{eV}$ for $\mathrm{FeS}_{2} / \mathrm{TiO}_{2}$ hybrid catalyst vs. $3.1 \mathrm{eV}$ for $\mathrm{TiO}_{2}$ ). As a result, in $\mathrm{FeS}_{2} / \mathrm{TiO}_{2}$ catalysts electrons are more easily promoted from the valence band to the conduction band, resulting in a higher photocatalytic activity. Similarly, Kuo, Li, Lin, Wang and co-workers prepared $\mathrm{FeS}_{2}-\mathrm{TiO}_{2}$ nanocrystals, whose absorption range is even extended from the UV-visible to the near-infrared region [61]. As a part of this work, they studied the $\mathrm{FeS}_{2}-\mathrm{TiO}_{2}$-catalyzed HER from a 50\% aqueous methanol solution and tested $\mathrm{FeS}_{2}-\mathrm{TiO}_{2}$ composites with different $\mathrm{FeS}_{2}$ loadings. Similar to the work by Lee and Kang, these $\mathrm{FeS}_{2}-\mathrm{TiO}_{2}$ heterostructures show remarkably enhanced hydrogen production rates in comparison with pure $\mathrm{FeS}_{2}$ nanoparticles and pure $\mathrm{TiO}_{2}$ (see Figure 4A). Figure 4B depicts a schematic action mechanism of the $\mathrm{FeS}_{2}-\mathrm{TiO}_{2}$ hybrid catalysts: when the material is irradiated with a broadband light source (covering UV, visible and IR (infrared) irradiation), photo-induced electrons are simultaneously promoted into the conduction bands of $\mathrm{TiO}_{2}$ and $\mathrm{FeS}_{2}$ by UV light and visible-NIR light, respectively. Subsequently, electron transfer occurs from the conduction band of $\mathrm{FeS}_{2}$ to that of $\mathrm{TiO}_{2}$, where protons are reduced to hydrogen. In this process it is the heterostructure between $\mathrm{TiO}_{2}$ nanoparticles and $\mathrm{FeS}_{2}$ nanocrystals which is key for the enhanced photocatalytic activity since it enables fast electron transfer 
from $\mathrm{FeS}_{2}$ to $\mathrm{TiO}_{2}$. Zhang and co-workers developed a comparable $\mathrm{FeS}_{2} / \mathrm{TiO}_{2}$ hybrid photocatalyst to use near-infrared light for photoelectrical water-splitting and demonstrate that $\mathrm{TiO}_{2}$ nanotubes decorated with infrared light responsive $\mathrm{FeS}_{2}$ exhibit excellent water-splitting performance under illumination of day light (Figure 4C) [62]. Under irradiation by solar light these $\mathrm{FeS}_{2} / \mathrm{TiO}_{2}$ nanotube catalysts cause a photocurrent enhancement, which is more than three orders of magnitude higher than that reached with pristine $\mathrm{TiO}_{2}$ nanotube electrodes under illumination of infrared light.
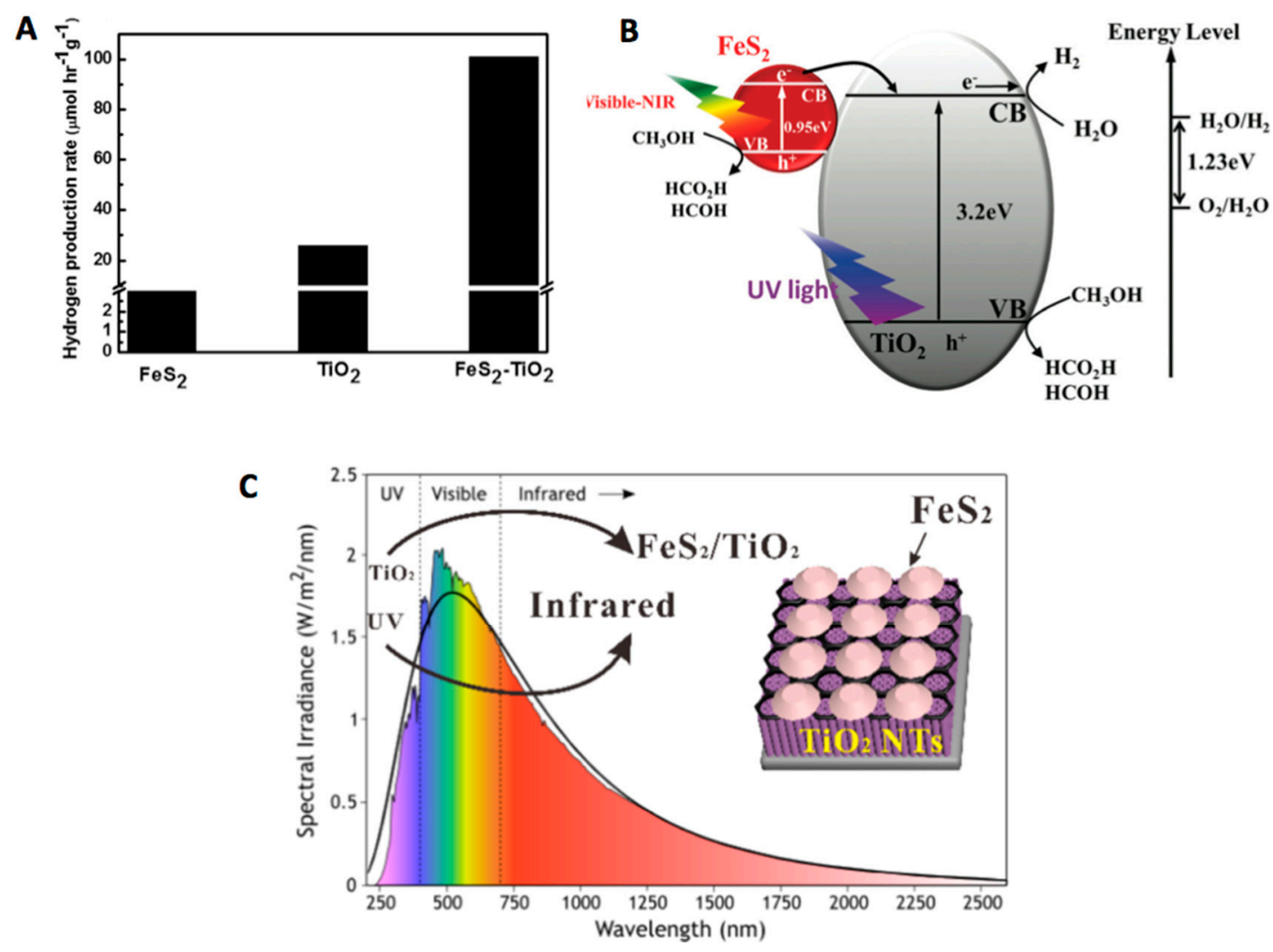

Figure 4. (A) Hydrogen evolution rate of $\mathrm{FeS}_{2}, \mathrm{TiO}_{2}$ and $\mathrm{FeS}_{2}-\mathrm{TiO}_{2}$ heterostructures under a $300 \mathrm{~W}$ xenon lamp; (B) schematic illustration of the photo-induced charge transfer in $\mathrm{FeS}_{2}-\mathrm{TiO}_{2}$ heterostructures under UV, visible, and near-infrared light irradiation. (A) and (B) reprinted with permission from reference [61]; (C) $\mathrm{TiO}_{2}$ nanotubes doped with $\mathrm{FeS}_{2}$ exhibit high photoelectrochemical performance in the infrared light region, reprinted with permission from reference [62].

\section{Iron Sulfide-2D Carbon Hybrid Materials}

The deposition of catalyst components on a support material is a common strategy in heterogeneous catalysis, which helps minimize the agglomeration of the catalyst particles and hence increases the total catalytically active surface area. Particularly for the design of electrocatalysts the right choice of support material is of great significance to target catalyst composites with high electron transport capacity, which helps avoid recombination of photogenerated charge carriers to guarantee good electrocatalytic performance. In this context, 2D materials such as graphene, reduced graphene oxide, $h$-boron nitride, monolayer $\mathrm{MS}_{2}(\mathrm{M}=\mathrm{Mo}, \mathrm{W})$ or monolayer $\mathrm{MoCh}(\mathrm{Ch}=\mathrm{Se}, \mathrm{Te})$ [63] are commonly used support media for electrocatalysts. For instance, Chen, Lee et al. have shown that platinum nanoparticles supported on reduced graphene oxide exhibit a higher electrocatalytic activity and superior stability than bare platinum nanoparticles [64] and other studies reveal the high efficiency of $\mathrm{Mo}_{2} \mathrm{C} / \mathrm{rGO}$ hybrid catalysts for hydrogen evolution [65]. The number of reported iron sulfide-carbon hybrid structures is surprisingly small and this section highlights the value of such materials for HER, with a focus on composites involving the 2D substrates Graphene (G), Graphene Oxide (GO) and reduced Graphene Oxide (rGO) [66-68]. 


\section{1. $\mathrm{FeS}_{2} / \mathrm{rGO}$ Hybrid Catalysts}

$\mathrm{Hu}$ and co-workers report the synthesis of nano-FeS $2-\mathrm{rGO}$, a material with $\mathrm{FeS}_{2}$ nanoparticles embedded in rGO, which has great potential as a high-performance electrocatalyst for HER [69]. Crucial is the high-temperature-assisted synthetic procedure delivering this nano- $\mathrm{FeS}_{2}-\mathrm{rGO}$ hybrid catalyst, which comprises the in situ synthesis of $\mathrm{FeS}_{2}$ nanoparticles from microscopic $\mathrm{FeS}_{2}$ powder in an rGO matrix (Figure 5). In the first reaction step microscopic $\mathrm{FeS}_{2}$ powder is obtained from bulk iron pyrite with a hammer and then mixed with GO, which has previously been exfoliated from graphite using an improved Hummers' method $[68,70]$. Subsequently, the obtained micro- $\mathrm{FeS}_{2}-\mathrm{rGO}$ material is exposed to a thermal shock $(2470 \mathrm{~K}, 12 \mathrm{~ms})$ initiating the decomposition of $\mathrm{FeS}_{2}$ into $\mathrm{Fe}$ and $\mathrm{S}$ atoms, which diffuse between the rGO layers. As rapid cooling takes place, the Fe and $\mathrm{S}$ atoms renucleate around the defects of the rGO sheets to form $\mathrm{FeS}_{2}$ nanoparticles. The authors envisage that this synthetic strategy could also be applied to target other transition metal multicomponent composites. Nano-FeS $2-\mathrm{rGO}$ exhibits an excellent HER activity achieving $10 \mathrm{~mA} \mathrm{~cm}{ }^{-2}$ at $139 \mathrm{mV}$ overpotential. Importantly, the rGO matrix does not only act as a physical support for the pyrite nanoparticles, but (1) leads to an outstanding chemical stability of the pyrite particles under acidic conditions, (2) increases the electronic conductivity of the catalyst material and (3) hinders the loss of pyrite nanoparticles from the material during the water-splitting process [69].

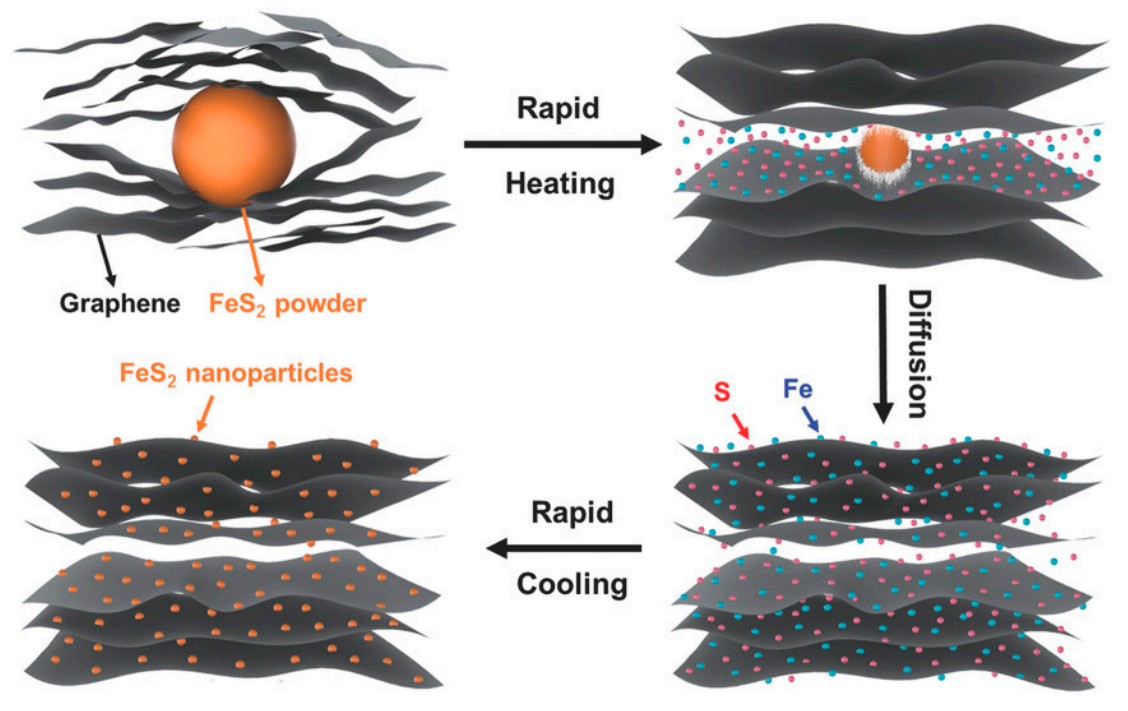

Figure 5. Ultrafast transformation of microscopic $\mathrm{FeS}_{2}$ mineral into $\mathrm{FeS}_{2}$ nanoparticles: A thermal shock ( $2470 \mathrm{~K}, 12 \mathrm{~ms}$ ) initiates the decomposition of $\mathrm{FeS}_{2}$ into $\mathrm{Fe}$ and $\mathrm{S}$ atoms. Subsequent recrystallization of $\mathrm{Fe}$ and $\mathrm{S}$ atoms at rGO defects delivers nano- $\mathrm{FeS}_{2}-\mathrm{rGO}$. Reprinted with permission from reference [69].

A similar $\mathrm{FeS}_{2}$-rGO hybrid catalyst has been synthesized by Jiang and co-workers through a hydrothermal synthesis from $\mathrm{rGO}, \mathrm{Fe}\left(\mathrm{NO}_{3}\right)_{3}$ and thioacetamide. This $\mathrm{FeS}_{2}$-rGO material consists of hexagonal $\mathrm{FeS}_{2}$ nanoclusters embedded in a lamellar rGO matrix and its electrochemical performance is superior to that of several iron-based catalysts [71]. The excellent electrical conductivity of rGO ensures a high electron transport capacity and small impedance $\left(R_{c t}=7.94 \Omega\right)$. Furthermore, the hybrid catalyst has a smaller Tafel slope $\left(61 \mathrm{mV} \mathrm{dec}^{-1}\right)$ than FeP nanosheets $\left(67 \mathrm{mV} \mathrm{dec}^{-1}\right)$ [72] or disk-shaped $\mathrm{FeS}_{2}$ nanoparticles $\left(76 \mathrm{mV} \mathrm{dec}^{-1}\right)$ [40].

\section{2. $\mathrm{MoS}_{2}$ and $\mathrm{Ni}$ Doped $\mathrm{FeS}_{2} / r \mathrm{GO}$ Hybrid Catalysts}

Taking the idea of $\mathrm{FeS}_{2}$-rGO composites a step further, Wang and co-workers have developed a three-tiered hybrid catalyst $\mathrm{FeS}_{2} @ \mathrm{MoS}_{2} / \mathrm{rGO}$ [73]. This electrocatalyst is fabricated from $\mathrm{FeCl}_{3}$, phosphomolybdic acid hydrate and L-cysteine and exhibits excellent HER activities as well as outstanding electrochemical durability. The rGO sheets provide the catalyst with excellent electrical 
conductivity and lead to high dispersion of both $\mathrm{MoS}_{2}$ sheets and $\mathrm{FeS}_{2}$ particles guaranteeing a high abundance of active sites. Furthermore, rGO triggers strong interactions between the other two components $\mathrm{MoS}_{2}$ and $\mathrm{FeS}_{2}$ endowing the catalyst composite with a high mechanical stability. Besides $\mathrm{MoS}_{2}$ also nickel doping of iron sulfide-rGO composites can have a positive effect on the hydrogen evolution activity. Jiang, Han and co-workers studied different nickel-doped $\mathrm{FeNi}_{x} \mathrm{~S}_{2}$-rGO electrocatalysts $(x=0.05-0.3)$ and found that the incorporation of nickel into iron sulfide nanostructures yields electrocatalysts with lower Tafel slope, smaller electrochemical impedance and reduced overpotential [74].

\section{3. $\mathrm{Fe}_{1-x} \mathrm{~S} / \mathrm{GO}$ Hybrid Catalyst}

Non-stoichiometric $\mathrm{Fe}_{1-x} \mathrm{~S}$ nanoparticles have been introduced into a sulfur-doped graphene oxide structure (S-GO) to produce nano-micro $\mathrm{Fe}_{1-x} \mathrm{~S} @ \mathrm{~S}-\mathrm{GO}$. This catalyst material was synthesized by a one-pot solvothermal approach in which aqueous solutions of $\mathrm{FeCl}_{3}, \mathrm{GO}$, and thioacetamide are heated in an autoclave for $15 \mathrm{~h}$ at $200{ }^{\circ} \mathrm{C}$ [75]. Hereby, thioacetamide decomposes to the parent sulfide $\mathrm{H}_{2} \mathrm{~S}$, which firstly reacts with $\mathrm{FeCl}_{3}$ to form $\mathrm{Fe}_{1-x} \mathrm{~S}$ nanoparticles and secondly converts $\mathrm{GO}$ to sulfur-doped GO (S-GO). The so-obtained $\mathrm{Fe}_{1-x} \mathrm{~S} @ S$-GO hybrid catalyst was used as cathode material in a dye-sensitized solar cell and achieves a high solar-to-electrical conversion efficiency up to $7.23 \%$ [75]. The $\mathrm{Fe}_{1-x} \mathrm{~S} @ S-G O$ composite has not yet been tested for HER; however, Wang, Zhou, and co-workers highlight its potential for solar water-splitting.

\section{4. $\mathrm{Fe}_{4} \mathrm{~S}_{4} /$ Graphene Hybrid Catalyst}

To finish this section about iron sulfide-carbon hybrid catalysts, one example of a molecular iron sulfide compound immobilized on graphene shall be highlighted. Begum and co-workers report $\mathrm{Fe}_{4} \mathrm{~S}_{4}$ cubane clusters on graphene as high-performance $\mathrm{H}_{2}$ evolution catalyst in acidic water [76]. $\left[\mathrm{PPh}_{4}\right]_{2}\left[\mathrm{Fe}_{4}\left(\mu_{3}-\mathrm{S}\right)_{4}(\mathrm{DMET})_{4}\right]$ (A) (DMET = cis-1,2-dicarbomethoxyethylene dithiolate) was prepared from $\left[\mathrm{PPh}_{4}\right]_{4}\left[\mathrm{Fe}_{2} \mathrm{~S}_{12}\right]$, dimethylacetylene dicarboxylate, and lithium sulfide. Subsequently, cluster compound $\mathbf{A}$ was ultrasonicated with functionalized graphene for $10 \mathrm{~h}$ under an argon atmosphere to yield A@graphene (Figure 6). A itself catalyzes the hydrogen evolution from tosylic acid (TON, 400); however, the hybrid catalyst A@graphene shows enhanced catalytic activity (TON, 3200) and higher stability in water compared to the naked complex A. Likely, the remarkable catalytic activity of A@graphene can be explained by continuous in situ reduction of $\mathbf{A}$ through the graphene support: $\mathbf{A}$ is oxidized during the proton reduction process and then immediately reduced by the graphene matrix, which acts as an external sacrificial electron donor. In extension to this work, research by Kanatzidis and co-workers shows that redox active $\mathrm{Fe}_{4} \mathrm{~S}_{4}$ clusters incorporated in dye-functionalized gels are capable of producing hydrogen under photochemical conditions $[77,78]$.

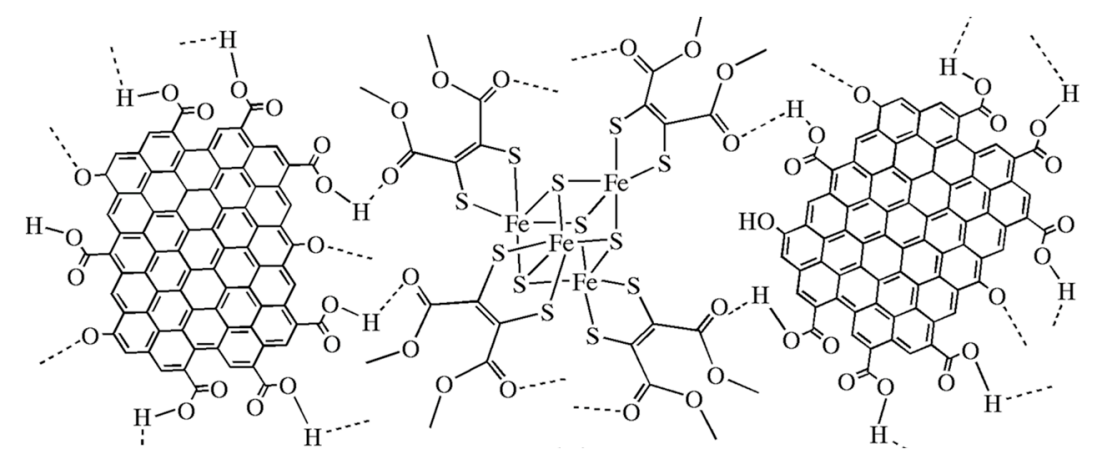

Figure 6. H-bonding interactions in $\left[\mathrm{PPh}_{4}\right]_{2}\left[\mathrm{Fe}_{4}\left(\mu_{3}-\mathrm{S}\right)_{4}(\mathrm{DMET})_{4}\right] @$ graphene. Reprinted with permission from reference [76]. 


\section{Metal Doping of Iron Sulfide Nanomaterials}

It has been shown in the previous section how the right choice of support material can significantly enhance the activity of iron sulfide electrocatalysts. A different approach to further improve these materials for electrochemical applications is their combination with other metallic elements or metal compounds. Most notably, the incorporation of elemental cobalt or cobalt phases into iron sulfide structures delivers new materials with remarkable HER activity.

\subsection{Cobalt-Doped FeS 2 Structures}

Huang, Luiso, Fedkiw and co-workers synthesized and investigated cobalt-doped iron sulfides $\mathrm{Fe}_{x} \mathrm{Co}_{1-x} \mathrm{~S}_{2}(x=0.98-0.32)$ on a carbon black support (Ketjenblack) and carried out a systematic study on the role of cobalt dopant for the hydrogen evolution activity of these materials [79]. Indeed, electrochemical measurements indicate a significant enhancement in HER activity of the Co-doped $\mathrm{FeS}_{2}$ structures in comparison to un-doped $\mathrm{FeS}_{2}$. Among the catalysts examined, $\mathrm{Fe}_{0.50} \mathrm{Co}_{0.50} \mathrm{~S}_{2}$ (on $\mathrm{HNO}_{3}$ oxidized Ketjenblack) exhibited the highest HER activity. The overpotential necessary to reach a current density of $10 \mathrm{~mA} / \mathrm{cm}^{2}$ was $150 \mathrm{mV}\left(229 \mathrm{mV}\right.$ for un-doped $\left.\mathrm{FeS}_{2}\right)$ and only decreased by $1 \mathrm{mV}$ after 500 catalytic cycles, indicating a long-term durability of the catalyst material in acidic environment.

A cobalt-doped iron pyrite catalyst with a phosphide surface modification $\left(\mathrm{P} / \mathrm{Co}-\mathrm{FeS}_{2}\right)$ has been prepared by Chen, Wang and co-workers via solvothermal and chemical vapor deposition approaches [80]. In a hydrothermal process cobalt-doped iron oxide is grown on carbon fiber paper by reaction of iron nitrate and cobalt nitrate. This material is then treated with elemental sulfur at $450{ }^{\circ} \mathrm{C}$ to form the cobalt-doped iron pyrite structure $\mathrm{Co}_{-} \mathrm{FeS}_{2}$. Finally, annealing of this material with sodium hypophosphite results in the formation of $\mathrm{P} / \mathrm{Co}-\mathrm{FeS}_{2}$, a phosphide-modified nanocomposite of $\mathrm{Co}-\mathrm{FeS}_{2}$. This catalyst material exhibits high HER activity with a low overpotential of $90 \mathrm{mV}$ (at $100 \mathrm{~mA} \mathrm{~cm}^{-2}$ ) and a high durability in acidic solutions.

Cobalt-doped $\mathrm{FeS}_{2}$ nanosheets hybridized with carbon nanotubes (CNT) $\mathrm{Fe}_{1-x} \mathrm{Co}_{x} \mathrm{~S}_{2} / \mathrm{CNT}$ also hold great potential for efficient HER in acidic solutions. Hwang, Chen, Dai, and co-workers report a scalable solvothermal synthesis of such $\mathrm{Fe}_{0.9} \mathrm{Co}_{0.1} \mathrm{~S}_{2}$-CNT structures and performed DFT (density functional theory) calculations to elucidate the role of cobalt doping for HER activity [81]. The theoretical investigations showed that the reaction in acidic solution first proceeds via proton adsorption and reduction on the catalyst surface to form hydrogen atoms, which are adsorbed on catalyst edges. Subsequently, $\mathrm{H}_{2}$ is formed and finally released in a desorption step, which also occurs on the catalyst edges (Figure 7). Notably, sulfur atoms on the edge of the catalyst were found to be the HER active sites. Comparison of the kinetic energy barrier profiles of the $\mathrm{Fe}_{0.9} \mathrm{Co}_{0.1} \mathrm{~S}_{2}-\mathrm{CNT}$ (Figure 7B top) and $\mathrm{FeS}_{2}$-CNT (Figure 7B bottom) catalyzed HER reveals a significant difference in the activation barrier of hydrogen atom adsorption leading to transition state 1 (TS1). In case of the $\mathrm{Fe}_{0.9} \mathrm{Co}_{0.1} \mathrm{~S}_{2}-\mathrm{CNT}$ catalyzed HER, this energy barrier is $1.23 \mathrm{eV}$ and significantly lower than that for the $\mathrm{FeS}_{2}-\mathrm{CNT}$ catalyst $(1.62 \mathrm{eV})$. Most likely, this substantial difference $(0.39 \mathrm{eV})$ explains the higher catalytic activity of $\mathrm{Fe}_{1-x} \mathrm{Co}_{x} \mathrm{~S}_{2} / \mathrm{CNT}$ hybrid catalysts compared to that of $\mathrm{FeS}_{2}$-CNT composites.

\section{2. $\mathrm{FeS}_{2}-\mathrm{CoS}_{2}$ Hybrid Structures}

$\mathrm{Xi}$ and co-workers demonstrated that even overall water-splitting is possible with cobalt-doped pyrite $\mathrm{FeS}_{2}$ heterostructures. They developed $\mathrm{FeS}_{2} / \mathrm{CoS}_{2}$ interface nanosheets with abundant defects; a bifunctional electrocatalyst, which exhibits superior catalytic properties for both HER and OER in alkaline conditions [82]. A water-splitting device equipped with such $\mathrm{FeS}_{2} / \mathrm{CoS}_{2}$ electrodes requires at $25^{\circ} \mathrm{C}$ only a voltage of $1.47 \mathrm{~V}$ to drive a current density of $10 \mathrm{~mA} \mathrm{~cm}{ }^{-2}$. At elevated temperature $\left(60{ }^{\circ} \mathrm{C}\right)$ the activity of the catalyst is even superior, and a lower voltage of $1.37 \mathrm{~V}$ is needed to afford the same current density. Remarkably, the performance of this $\mathrm{FeS}_{2} / \mathrm{CoS}_{2}$ catalyst is better than that of most reported non-noble metal overall water-splitting catalysts (see Figure 8). This 
example highlights the significance of interface engineering for developing highly efficient and stable water-splitting electrocatalysts.
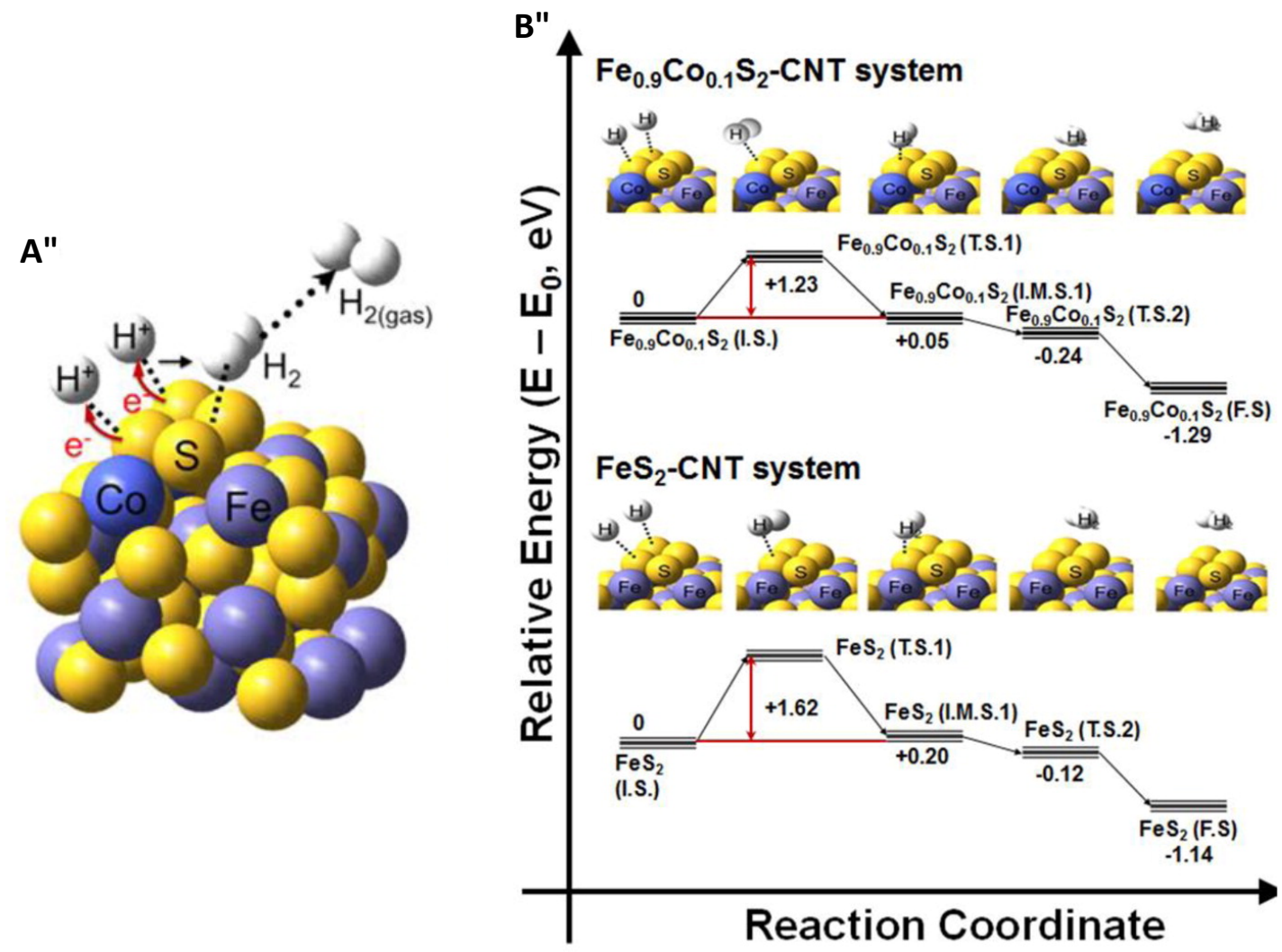

Figure 7. (A) Schematic reaction of hydrogen evolution occurring on a sulfur atom of $\mathrm{Fe}_{0.9} \mathrm{Co}_{0.1} \mathrm{~S}_{2}$. (B) Kinetic energy barrier profiles of HER on $\mathrm{Fe}_{0.9} \mathrm{Co}_{0.1} \mathrm{~S}_{2}-\mathrm{CNT}$ (top) and $\mathrm{FeS}_{2}-\mathrm{CNT}$ (bottom) catalysts. Reprinted with permission from reference [81].

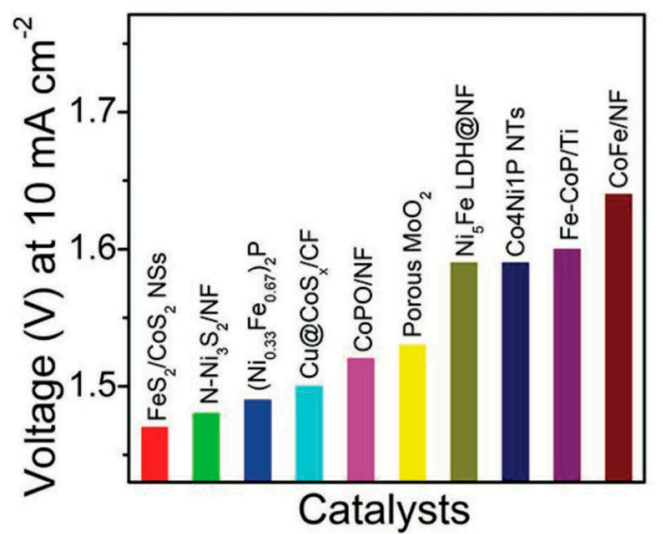

Figure 8. Comparison of the voltage for $\mathrm{FeS}_{2} / \mathrm{CoS}_{2}$ interface nanosheets catalyst (red) with other reported non-noble metal overall water-splitting catalysts (at $10 \mathrm{~mA} \mathrm{~cm}^{-2}$ ). Reprinted with permission from reference [82].

\subsection{Cobalt-Doped $\mathrm{FeS}_{2}-\mathrm{CoS}_{2}$ Hybrid Structures}

Yan, Shi and co-workers merged the two concepts of cobalt doping and the hybridization of $\mathrm{CoS}_{2}$ and $\mathrm{FeS}_{2}$ pyrite structures (vide supra 5.1 and 5.2) to produce heterostructures of the type $\mathrm{Co}-\mathrm{Fe} \mathrm{S}_{2} / \mathrm{CoS}_{2}$, which can be prepared from cobalt-doped $\mathrm{FeS}_{2}$ and $\mathrm{CoS}_{2}$. Benefitting from a three-dimensional hierarchical nanoarchitecture, which maximizes the exposure of accessible active 
sites, these $\mathrm{Co}-\mathrm{FeS}_{2} / \mathrm{CoS}_{2}$ electrocatalysts exhibited excellent activity for hydrogen and oxygen evolution reactions [83]. The materials' distinctive nanostructure not only endows the catalyst with a large surface area, but also assists the release of hydrogen and oxygen from the electrode surface. The superior oxygen evolution performance of $\mathrm{Co}-\mathrm{FeS}_{2} / \mathrm{CoS}_{2}$ heterostructures $(278 \mathrm{mV}$ overpotential at $10 \mathrm{~mA} \mathrm{~cm}^{-2}$ in $1 \mathrm{M} \mathrm{KOH}$ ) is mainly explained by the presence of the $\mathrm{CoS}_{2}$ phase and its co-existence as heterostructure with $\mathrm{Co}-\mathrm{FeS}_{2}$. The overpotential for HER in $0.5 \mathrm{M} \mathrm{H}_{2} \mathrm{SO}_{4}$ solution is $103 \mathrm{mV}(10 \mathrm{~mA}$ $\mathrm{cm}^{-2}$ ) and both overpotential values of OER and HER change only marginally after 1000 catalytic cycles by $5 \mathrm{mV}$ and $3 \mathrm{mV}$, respectively.

\section{4. $\mathrm{FeS}_{2}$-Doped $\mathrm{MoS}_{2}$ Nanoflowers}

Instead of doping iron disulfide with metals or metal compounds, $\mathrm{FeS}_{2}$ itself can be employed as dopant and be incorporated in trace levels into a guest crystal lattice. $\mathrm{MoS}_{2}$ nanomaterials are known to be efficient catalysts for hydrogen evolution [17] and to further enhance the HER efficiency of $\mathrm{MoS}_{2}$, Yang and co-workers have prepared $\mathrm{MoS}_{2}$ nanoflowers (predominately 1T-MoS 2 ) and doped them with $\mathrm{FeS}_{2}$ [84]. Due to a unique morphology and electronic structure this $\mathrm{FeS}_{2}$-doped molybdenum sulfide material exhibits exceptional performance as HER electrocatalyst, which is superior to that of pure $\mathrm{MoS}_{2}$ and pure $\mathrm{FeS}_{2}$.

\section{Conclusions and Outlook}

The development of iron sulfide catalysts for electrochemical hydrogen evolution is a rapidly growing research field, of which selected milestones are summarized in this article. Even though iron sulfide electrocatalysts are still less developed and typically less effective HER catalysts than noble metal systems, numerous examples of well-designed iron sulfide materials exhibit surprising catalytic performance. In particular, the presence of disulfide moieties $\mathrm{S}_{2}{ }^{2-}$ causes a high catalytic HER activity and thus especially $\mathrm{FeS}_{2}$ materials are attractive electrocatalysts for hydrogen evolution. Importantly, iron sulfide catalysts seem to be less prone to sulfide poisoning than noble metal catalysts. Composite materials of iron sulfide structures with 2D-carbon nanomaterials exhibit frequently better electrocatalytic performance and chemical robustness than pure iron sulfides. Comparably, doping of iron sulfide phases with other metals or other transition metal compounds delivers highly reactive HER catalysts. All in all, these examples show that the development of new iron sulfide containing electrocatalysts and further improvement of existing materials is urgently needed to exploit the maximum potential of a hitherto overlooked catalyst family for hydrogen evolution.

Funding: This research was funded by ERDF (COAST project), grant number 25R16P01359.

Acknowledgments: D.H. is thankful for fruitful discussions with P.W. Dyer and with all COAST team members. Conflicts of Interest: The author declares no conflict of interest.

\section{Appendix A. Summary Table of Discussed Iron Sulfide Materials}

Synthetic procedures for all discussed iron sulfide nanomaterials and specific characteristic data such as HER overpotential and Tafel slope (the slope of a curve of overpotential in Volts versus the logarithm of current density) are collected in this appendix of the review and provide a summary of their activity and performance as HER electrocatalysts. Importantly, quantitative comparison of the catalysts' HER performance is a challenging task and care should be taken because of differences in the electrode preparation, the amount of employed catalyst material and the electrolyte ( $\mathrm{pH}$ conditions). 
Table A1. Synthetic procedures and HER performance data (Tafel slope $\left(\mathrm{mV} \mathrm{dec}{ }^{-1}\right)$, over potential $\eta$ $(\mathrm{mV}))$ for discussed iron sulfide materials.

\begin{tabular}{|c|c|c|c|c|c|}
\hline Catalyst & Synthetic Procedure & Electrolyte & $\begin{array}{l}\text { Tafel } \\
\text { Slope }\end{array}$ & $\begin{array}{c}\eta \text { HER } \\
\left(X \mathrm{~mA} \mathrm{~cm}^{-2}\right)\end{array}$ & Ref. \\
\hline \multicolumn{6}{|c|}{ Iron sulfides } \\
\hline $\mathrm{Fe} @ \mathrm{FeO}_{x} \mathrm{~S}_{y}$ & $\begin{array}{l}\text { FeS nanosheets on iron } \\
\text { foam }\end{array}$ & $1 \mathrm{M} \mathrm{KOH}$ & 77 & $243(100)$ & [34] \\
\hline FeS NPs on Nafion & $\begin{array}{c}\text { Decomposition of } \\
\mathrm{Fe}_{2} \mathrm{~S}_{2}(\mathrm{CO})_{6}\end{array}$ & $\mathrm{pH} 7$ & 150 & $\sim 450(0.71)$ & [35] \\
\hline $\mathrm{FeS}_{2}$ discs & Hot-injection procedure & & 76 & & \\
\hline $\mathrm{FeS}_{2}$ wires & with $\mathrm{FeI}_{2}$ and $\mathrm{S}_{8}$ in & $\mathrm{pH} 7$ & 91 & - & [40] \\
\hline $\mathrm{FeS}_{2}$ cubes & different rations & & 200 & & \\
\hline $\mathrm{FeS}_{2} / \mathrm{C} \mathrm{NPs}$ & $\begin{array}{l}\text { Hydrothermal process } \\
\text { from } \mathrm{FeCl}_{3} \cdot\left(\mathrm{H}_{2} \mathrm{O}\right)_{6} \text { and } \\
\text { diethyl- dithio-carbamate } \\
\text { trihydrate }\end{array}$ & $1 \mathrm{M} \mathrm{KOH}$ & 98 & $202(10)$ & [44] \\
\hline Mesoporous $\mathrm{FeS}_{2}$ & $\begin{array}{c}\text { Conversion of } \\
\text { mesoporous } \mathrm{Fe}_{2} \mathrm{O}_{3} \text { with } \\
\mathrm{H}_{2} \mathrm{~S} \text { and } \mathrm{S}_{8} \text { into } \\
\text { mesoporous } \mathrm{FeS}_{2}\end{array}$ & $\mathrm{pH} 13$ & 78 & $96(10)$ & [43] \\
\hline $\mathrm{FeS}_{2}$ thin-films & Atomic Layer Deposition & - & - & - & [49] \\
\hline $\begin{array}{c}\text { Cathode in PEM } \\
\text { electrolyzer } \\
\mathrm{FeS}_{2} / \mathrm{C} \\
\mathrm{Fe}_{3} \mathrm{~S}_{4} / \mathrm{C} \\
\mathrm{Fe}_{9} \mathrm{~S}_{10} / \mathrm{C}\end{array}$ & $\begin{array}{l}\text { Polyol method from } \\
\mathrm{FeCl}_{3} \text { and thiourea }\end{array}$ & pH 7 & $\begin{array}{l}204 \\
224 \\
234\end{array}$ & - & [55] \\
\hline $\begin{array}{l}\mathrm{pH} \text { dependence of } \\
\mathrm{FeS}_{2} \text {-catalyzed HER }\end{array}$ & $\begin{array}{l}\text { Polyol method from } \\
\mathrm{FeCl}_{3} \text { and thiourea }\end{array}$ & $\begin{array}{c}\mathrm{pH} \\
0.3 \\
1 \\
2 \\
3 \\
4 \\
5 \\
6 \\
7 \\
9 \\
11 \\
13\end{array}$ & $\begin{array}{c}85 \\
127 \\
170 \\
290 \\
306 \\
340 \\
287 \\
280 \\
274 \\
329 \\
192\end{array}$ & - & [54] \\
\hline \multicolumn{6}{|c|}{$\mathrm{FeS}_{2}-\mathrm{TiO}_{2}$ materials } \\
\hline $\begin{array}{c}\mathrm{FeS}_{2} / \mathrm{TiO}_{2} \text { core-shell } \\
\text { composites }\end{array}$ & $\begin{array}{c}\text { Deposition of } \mathrm{FeS}_{2} \mathrm{NPs} \\
\text { (solvothermal from } \mathrm{FeCl}_{3} \\
\text { and } \mathrm{Na}_{2} \mathrm{~S}_{2} \mathrm{O}_{3} \text { ) on } \\
\text { nano-sized } \mathrm{TiO}_{2}\end{array}$ & $\begin{array}{c}\mathrm{MeOH} / \mathrm{H}_{2} \mathrm{O} \\
(1: 1)\end{array}$ & - & - & [60] \\
\hline $\mathrm{FeS}_{2}-\mathrm{TiO}_{2}$ heterostructures & $\begin{array}{l}\text { Injection of } \mathrm{S}_{8} \text {-oleylamine } \\
\text { mixture in solution } \\
\text { containing } \\
\mathrm{TiO}_{2} \text {-octadecene and } \\
\text { Fe-oleic acid precursors }\end{array}$ & $\begin{array}{c}\mathrm{MeOH} \\
\mathrm{EtOH} \\
\mathrm{H}_{2} \mathrm{O} \\
\mathrm{Na}_{2} \mathrm{~S} \text { aq. } \\
\mathrm{Na}_{2} \mathrm{~S} / \mathrm{Na}_{2} \mathrm{SO}_{3} \\
\text { solution }\end{array}$ & - & - & [61] \\
\hline $\begin{array}{c}\mathrm{FeS}_{2} \text { sensitized } \mathrm{TiO}_{2} \\
\text { nanotubes }\end{array}$ & $\begin{array}{c}\text { Deposition of } \mathrm{FeS}_{2} \text { (from } \\
\mathrm{FeCl}_{3} \text { and thiourea) on } \\
\mathrm{TiO}_{2} \text { nanotubes }\end{array}$ & $\mathrm{pH} 7.4$ & - & - & [62] \\
\hline
\end{tabular}


Table A1. Cont.

\begin{tabular}{|c|c|c|c|c|c|}
\hline Catalyst & Synthetic Procedure & Electrolyte & $\begin{array}{l}\text { Tafel } \\
\text { Slope }\end{array}$ & $\begin{array}{c}\eta \text { HER } \\
\left(X \mathrm{~mA} \mathrm{~cm}^{-2}\right)\end{array}$ & Ref. \\
\hline \multicolumn{6}{|c|}{ Iron sulfide-2D carbon hybrid materials } \\
\hline nano-FeS 2 -rGO & $\begin{array}{c}\text { Current-induced } \\
\text { high-temperature thermal } \\
\text { shock process }\end{array}$ & $0.5 \mathrm{M} \mathrm{H}_{2} \mathrm{SO}_{4}$ & 66 & $139(10)$ & [69] \\
\hline $\mathrm{FeS}_{2}-\mathrm{rGO}$ & $\begin{array}{c}\text { Hydrothermal reduction } \\
\text { process }\end{array}$ & $0.5 \mathrm{M} \mathrm{H}_{2} \mathrm{SO}_{4}$ & 61 & $226(10)$ & {$[71]$} \\
\hline $\mathrm{FeS}_{2} @ \mathrm{MoS}_{2} / \mathrm{rGO}$ & $\begin{array}{l}\text { Autoclave reaction of } \\
\mathrm{FeCl}_{3} \text {, phosphomolybdic } \\
\text { acid hydrate and } \\
\text { L-cysteine }\end{array}$ & $0.5 \mathrm{M} \mathrm{H}_{2} \mathrm{SO}_{4}$ & 38.4 & $123(10)$ & {$[73]$} \\
\hline $\mathrm{FeNi}_{0.05} \mathrm{~S}_{2}$-rGO & & & 74.46 & 232 & \\
\hline $\mathrm{FeNi}_{0.10} \mathrm{~S}_{2}$-rGO & High-temperature & & 71.96 & 225 & \\
\hline $\mathrm{FeNi}_{0.15} \mathrm{~S}_{2}$-rGO & hydrothermal method & $05 \mathrm{MH}$ & 76.96 & 198 & {$[74]$} \\
\hline $\mathrm{FeNi}_{0.20} \mathrm{~S}_{2}-\mathrm{rGO}$ & from $\mathrm{GO}, \mathrm{FeCl}_{3}, \mathrm{NiCl}_{2}$ & $0.5 \mathrm{IN}_{2} \mathrm{SU}_{4}$ & 78.36 & 183 & {$[/ 4]$} \\
\hline $\mathrm{FeNi}_{0.25} \mathrm{~S}_{2}$-rGO & and thioacetamide & & 82.82 & 209 & \\
\hline $\mathrm{FeNi}_{0.30} \mathrm{~S}_{2}$-rGO & & & 79.19 & $260(10)$ & \\
\hline nano-micro Fe ${ }_{1-x} \mathrm{~S} @ S-G O$ & $\begin{array}{l}\text { Autoclave reaction of } \\
\text { aqueous solutions of } \\
\mathrm{FeCl}_{3}, \mathrm{GO} \text {, and } \\
\text { thioacetamide }\end{array}$ & - & - & - & [75] \\
\hline $\begin{array}{c}{\left[\mathrm{PPh}_{4}\right]_{2}\left[\mathrm{Fe}_{4}\left(\mu_{3^{-}}\right.\right.} \\
\left.\mathrm{S})_{4}(\mathrm{DMET})_{4}\right] @ \text { graphene }\end{array}$ & $\begin{array}{l}\text { Ultrasonication of } \mathrm{Fe}_{4} \mathrm{~S}_{4} \\
\text { cubane type cluster with } \\
\text { functionalized graphene }\end{array}$ & $\begin{array}{l}p \text {-toluene } \\
\text { sulfonic acid }\end{array}$ & - & - & [76] \\
\hline \multicolumn{6}{|c|}{ Metal-doped iron sulfide materials } \\
\hline $\begin{array}{c}\mathrm{Fe}_{0.50} \mathrm{Co}_{0.50} \mathrm{~S}_{2} \text { on } \\
\text { Ketjenblack oxidized with } \\
10 \mathrm{~N} \text { nitric acid }\end{array}$ & $\begin{array}{c}\text { Chemical sulfurization of } \\
\text { metal precursors using } \\
\mathrm{H}_{2} \mathrm{~S}\end{array}$ & $0.5 \mathrm{M} \mathrm{H}_{2} \mathrm{SO}_{4}$ & 52 & $150(10)$ & [79] \\
\hline $\mathrm{P} / \mathrm{Co}-\mathrm{FeS}_{2}$ & $\begin{array}{l}\text { Hydrothermal process of } \\
\text { iron nitrate and cobalt } \\
\text { nitrate followed by CVD } \\
\text { treatment with } S_{8}\end{array}$ & $0.5 \mathrm{M} \mathrm{H}_{2} \mathrm{SO}_{4}$ & 41.5 & $90(100)$ & [80] \\
\hline $\mathrm{Fe}_{0.9} \mathrm{Co}_{0.1} \mathrm{~S}_{2} / \mathrm{CNT}$ & Solvothermal approach & $0.5 \mathrm{M} \mathrm{H}_{2} \mathrm{SO}_{4}$ & 46 & $120(20)$ & [81] \\
\hline $\begin{array}{c}\mathrm{FeS}_{2} / \mathrm{CoS}_{2} \text { interface } \\
\text { nanosheets }\end{array}$ & $\begin{array}{l}\text { Annealing of } \mathrm{CoFe}_{2} \mathrm{O}_{4} \\
\text { NPs with sulfur }\end{array}$ & $1 \mathrm{M} \mathrm{KOH}$ & 44 & $78.2(10)$ & [82] \\
\hline $\mathrm{Co}-\mathrm{FeS}_{2} / \mathrm{CoS}$ & $\begin{array}{l}\text { Hydrothermal process } \\
\text { from } \mathrm{FeSO}_{4}, \mathrm{Co}\left(\mathrm{NO}_{3}\right)_{2}, \\
\text { thiourea, and sulfur }\end{array}$ & $0.5 \mathrm{M} \mathrm{H}_{2} \mathrm{SO}_{4}$ & 56 & $103(10)$ & [83] \\
\hline $\mathrm{FeS}_{2}$-doped $\mathrm{MoS}_{2}$ & $\begin{array}{l}\text { Autoclave process of } \\
\mathrm{Na}_{2} \mathrm{Mo}_{4} \cdot 2 \mathrm{H}_{2} \mathrm{O} \text {, thiourea, } \\
\text { and } \mathrm{Fe}_{3} \mathrm{O}_{4} \text { microspheres }\end{array}$ & $0.5 \mathrm{M} \mathrm{H}_{2} \mathrm{SO}_{4}$ & 82 & $136(10)$ & [84] \\
\hline
\end{tabular}

\section{References}

1. Nandi, R.; Sengupta, S. Microbial production of hydrogen: An overview. Crit. Rev. Microbiol. 1998, $24,61-84$. [CrossRef]

2. Møller, K.T.; Jensen, T.R.; Akiba, E.; Li, H.W. Hydrogen-A sustainable energy carrier. Prog. Nat. Sci. Mater. 2017, 27, 34-40. [CrossRef]

3. Ryabchuk, V.K.; Kuznetsov, V.N.; Emeline, A.V.; Artem'ev, Y.M.; Kataeva, G.V.; Horikoshi, S.; Serpone, N. Water Will Be the Coal of the Future-The Untamed Dream of Jules Verne for a Solar Fuel. Molecules 2016, 21, 1638. [CrossRef] 
4. Hacker, V.; Fankhauser, R.; Faleschini, G.; Fuchs, H.; Friedrich, K.; Muhr, M.; Kordesch, K. Hydrogen production by steam-iron process. J. Power Sources 2000, 86, 531-535. [CrossRef]

5. Wang, Y.Q.; Jin, F.M.; Zeng, X.; Yao, G.D.; Jing, Z.Z. A novel method for producing hydrogen from water with Fe enhanced by $\mathrm{HS}^{-}$under mild hydrothermal conditions. Int. J. Hydrogen Energy 2013, 38, 760-768. [CrossRef]

6. Zou, X.X.; Zhang, Y. Noble metal-free hydrogen evolution catalysts for water splitting. Chem. Soc. Rev. 2015, 44, 5148-5180. [CrossRef]

7. Kang, J.; Hwang, J.; Han, B. First-Principles Computational Screening of Highly Active Pyrites Catalysts for Hydrogen Evolution Reaction through a Universal Relation with a Thermodynamic Variable. J. Phys. Chem. C 2018, 122, 2107-2112. [CrossRef]

8. Zhang, L.; Doyle-Davis, K.; Sun, X.L. Pt-Based electrocatalysts with high atom utilization efficiency: From nanostructures to single atoms. Energy Environ. Sci. 2019, 12, 492-517. [CrossRef]

9. Tachibana, Y.; Vayssieres, L.; Durrant, J.R. Artificial photosynthesis for solar water-splitting. Nat. Photonics 2012, 6, 511-518. [CrossRef]

10. Lubitz, W.; Ogata, H.; Rüdiger, O.; Reijerse, E. Hydrogenases. Chem. Rev. 2014, 114, 4081-4148. [CrossRef]

11. Simmons, T.R.; Berggren, G.; Bacchi, M.; Fontecave, M.; Artero, V. Mimicking hydrogenases: From biomimetics to artificial enzymes. Coord. Chem. Rev. 2014, 270, 127-150. [CrossRef]

12. Hosseini, M.R.; Sarvi, M.N. Recent achievements in the microbial synthesis of semiconductor metal sulfide nanoparticles. Mater. Sci. Semicond. Process. 2015, 40, 293-301. [CrossRef]

13. Kong, D.; Cha, J.J.; Wang, H.; Lee, H.R.; Cui, Y. First-row transition metal dichalcogenide catalysts for hydrogen evolution reaction. Energy Environ. Sci. 2013, 6, 3553-3558. [CrossRef]

14. Fu, H. Environmentally friendly and earth-abundant colloidal chalcogenide nanocrystals for photovoltaic applications. J. Mater. Chem. C 2018, 6, 414-445. [CrossRef]

15. Faber, M.S.; Lukowski, M.A.; Ding, Q.; Kaiser, N.S.; Jin, S. Earth-Abundant Metal Pyrites $\left(\mathrm{FeS}_{2}, \mathrm{CoS}_{2}, \mathrm{NiS}_{2}\right.$, and Their Alloys) for Highly Efficient Hydrogen Evolution and Polysulfide Reduction Electrocatalysis. J. Phys. Chem. C 2014, 118, 21347-21356. [CrossRef]

16. Gao, M.R.; Zheng, Y.R.; Jiang, J.; Yu, S.H. Pyrite-Type Nanomaterials for Advanced Electrocatalysis. Acc. Chem. Res. 2017, 50, 2194-2204. [CrossRef]

17. Zhang, Y.; Zhou, Q.; Zhu, J.X.; Yan, Q.Y.; Dou, S.X.; Sun, W.P. Nanostructured Metal Chalcogenides for Energy Storage and Electrocatalysis. Adv. Funct. Mater. 2017, 27. [CrossRef]

18. Wang, J.S.; Liu, J.; Zhang, B.; Ji, X.; Xu, K.; Chen, C.; Miao, L.; Jiang, J.J. The mechanism of hydrogen adsorption on transition metal dichalcogenides as hydrogen evolution reaction catalyst. Phys. Chem. Chem. Phys. 2017, 19, 10125-10132. [CrossRef]

19. Khalid, S.; Ahmed, E.; Khan, Y.; Riaz, K.N.; Malik, M.A. Nanocrystalline Pyrite for Photovoltaic Applications. Chemistryselect 2018, 3, 6488-6524. [CrossRef]

20. Bi, Y.; Yuan, Y.B.; Exstrom, C.L.; Darveau, S.A.; Huang, J.S. Air Stable, Photosensitive, Phase Pure Iron Pyrite Nanocrystal Thin Films for Photovoltaic Application. Nano Lett. 2011, 11, 4953-4957. [CrossRef]

21. Zhang, G.; Liu, H.; Qu, J.; Li, J. Two-dimensional layered $\mathrm{MoS}_{2}$ : Rational design, properties and electrochemical applications. Energy Environ. Sci. 2016, 9, 1190-1209. [CrossRef]

22. Su, J.Z.; Zhou, J.L.; Wang, L.; Liu, C.; Chen, Y.B. Synthesis and application of transition metal phosphides as electrocatalyst for water splitting. Sci. Bull. 2017, 62, 633-644. [CrossRef]

23. Sosa, E.; Cabrera-Sierra, R.; Oropeza, M.T.; Gonzalez, I. Stability study of iron sulfide films, electrochemically grown on carbon steel, in different electrolytic media. Corrosion 2002, 58, 659-669. [CrossRef]

24. Rickard, D.; Luther, G.W. Chemistry of Iron Sulfides. Chem. Rev. 2007, 107, 514-562. [CrossRef]

25. Matamoros-Veloza, A.; Cespedes, O.; Johnson, B.R.G.; Stawski, T.M.; Terranova, U.; de Leeuw, N.H.; Benning, L.G. A highly reactive precursor in the iron sulfide system. Nat. Commun. 2018, 9, 3125. [CrossRef]

26. Matamoros-Veloza, A.; Stawski, T.M.; Benning, L.G. Nanoparticle Assembly Leads to Mackinawite Formation. Cryst. Growth Des. 2018, 18, 6757-6764. [CrossRef]

27. Heift, D.; Lacroix, L.-M.; Lecante, P.; Fazzini, P.-F.; Chaudret, B. Controlling the Sulfidation Process of Iron Nanoparticles: Accessing Iron-Iron Sulfide Core-Shell Structures. ChemNanoMat 2018, 4, 663-669. [CrossRef]

28. Qin, H.; Jia, J.; Lin, L.; Ni, H.; Wang, M.; Meng, L. Pyrite FeS 2 nanostructures: Synthesis, properties and applications. Mater. Sci. Eng. B 2018, 236, 104-124. [CrossRef] 
29. Raturi, A.K.; Waita, S.; Aduda, B.; Nyangonda, T. Photoactive iron pyrite films for photoelectrochemical (PEC) cells. Renew. Energy 2000, 20, 37-43. [CrossRef]

30. Valand, T.; Burchardt, T.; van der Meer, S.F. The hydrogen evolution and corrosion of amorphous FeS $\mathrm{S}_{\mathrm{x}}$ films. Corros. Sci. 2001, 43, 147-156. [CrossRef]

31. Ennaoui, A.; Fiechter, S.; Pettenkofer, C.; Alonso-Vante, N.; Bueker, K.; Bronold, M.; Hoepfner, C.; Tributsch, H. Iron disulfide for solar energy conversion. Sol. Energy Mater. Sol. Cells 1993, 29, 289-370. [CrossRef]

32. Dasbach, R.; Willeke, G.; Blenk, O. Iron sulfide for photovoltaics. MRS Bull. 1993, 18, 56-60. [CrossRef]

33. Rui, X.; Tan, H.; Yan, Q. Nanostructured metal sulfides for energy storage. Nanoscale 2014, 6, 9889-9924. [CrossRef]

34. Zou, X.; Wu, Y.; Liu, Y.; Liu, D.; Li, W.; Gu, L.; Liu, H.; Wang, P.; Sun, L.; Zhang, Y. In Situ Generation of Bifunctional, Efficient Fe-Based Catalysts from Mackinawite Iron Sulfide for Water Splitting. Chem 2018, 4, 1139-1152. [CrossRef]

35. Di Giovanni, C.; Wang, W.-A.; Nowak, S.; Grenèche, J.-M.; Lecoq, H.; Mouton, L.; Giraud, M.; Tard, C. Bioinspired Iron Sulfide Nanoparticles for Cheap and Long-Lived Electrocatalytic Molecular Hydrogen Evolution in Neutral Water. ACS Catal. 2014, 4, 681-687. [CrossRef]

36. Tard, C.; Giraud, M. Iron Sulfide Based Catalyst for Electrolytic Water Reduction into Hydrogen Gas. WO2014207156A1, 31 December 2014.

37. Yersak, T.A.; Macpherson, H.A.; Kim, S.C.; Le, V.-D.; Kang, C.S.; Son, S.-B.; Kim, Y.-H.; Trevey, J.E.; Oh, K.H.; Stoldt, C.; et al. Solid State Enabled Reversible Four Electron Storage. Adv. Energy Mater. 2013, 3, 120-127. [CrossRef]

38. Murphy, R.; Strongin, D.R. Surface reactivity of pyrite and related sulfides. Surf. Sci. Rep. 2009, 64, 1-45. [CrossRef]

39. Huerta-Flores, A.M.; Torres-Martinez, L.M.; Moctezuma, E.; Singh, A.P.; Wickman, B. Green synthesis of earth-abundant metal sulfides $\left(\mathrm{FeS}_{2}, \mathrm{CuS}\right.$, and $\left.\mathrm{NiS}_{2}\right)$ and their use as visible-light active photocatalysts for $\mathrm{H}_{2}$ generation and dye removal. J. Mater. Sci. Mater. Electron. 2018, 29, 11613-11626. [CrossRef]

40. Jasion, D.; Barforoush, J.M.; Qiao, Q.; Zhu, Y.; Ren, S.; Leonard, K.C. Low-Dimensional Hyperthin FeS 2 Nanostructures for Efficient and Stable Hydrogen Evolution Electrocatalysis. ACS Catal. 2015, 5, 6653-6657. [CrossRef]

41. Ren, S.; Leonard, K.C.; Barforoush, J.M.; Jasion, D. Low-dimensional Hyperthin FeS 2 Nanostructures for Electrocatalysis. US20180222767A1, 9 August 2018.

42. Rouquerol, J.; Avnir, D.; Fairbridge, C.W.; Everett, D.H.; Haynes, J.H.; Pernicone, N.; Ramsay, J.D.F.; Sing, K.S.W.; Unger, K.K. Recommendations for the Characterization of Porous Solids. Pure Appl. Chem. 1994, 66, 1739-1758. [CrossRef]

43. Miao, R.; Dutta, B.; Sahoo, S.; He, J.; Zhong, W.; Cetegen, S.A.; Jiang, T.; Alpay, S.P.; Suib, S.L. Mesoporous Iron Sulfide for Highly Efficient Electrocatalytic Hydrogen Evolution. J. Am. Chem. Soc. 2017, 139, 13604-13607. [CrossRef]

44. Li, Z.; Xiao, M.; Zhou, Y.; Zhang, D.; Wang, H.; Liu, X.; Wang, D.; Wang, W. Pyrite FeS $2 / C$ nanoparticles as an efficient bi-functional catalyst for overall water splitting. Dalton Trans. 2018, 47, 14917-14923. [CrossRef]

45. Anantharaj, S.; Karthik, P.E.; Kundu, S. Self-assembled $\mathrm{IrO}_{2}$ nanoparticles on a DNA scaffold with enhanced catalytic and oxygen evolution reaction (OER) activities. J. Mater. Chem. A 2015, 3, 24463-24478. [CrossRef]

46. McCrory, C.C.L.; Jung, S.H.; Peters, J.C.; Jaramillo, T.F. Benchmarking Heterogeneous Electrocatalysts for the Oxygen Evolution Reaction. J. Am. Chem. Soc. 2013, 135, 16977-16987. [CrossRef]

47. Liu, H.F.; Chi, D.Z. Synthesis of iron sulfide and iron oxide nanocrystal thin films for green energy applications. Procedia Eng. 2016, 141, 32-37. [CrossRef]

48. Dasgupta, N.P.; Meng, X.; Elam, J.W.; Martinson, A.B.F. Atomic Layer Deposition of Metal Sulfide Materials. Acc. Chem. Res. 2015, 48, 341-348. [CrossRef]

49. Guo, Z.; Wang, X. Atomic Layer Deposition of the Metal Pyrites $\mathrm{FeS}_{2}, \mathrm{CoS}_{2}$, and $\mathrm{NiS}_{2}$. Angew. Chem. Int. Ed. 2018, 57, 5898-5902. [CrossRef]

50. Wu, L.; Dzade, N.Y.; Gao, L.; Scanlon, D.O.; Öztürk, Z.; Hollingsworth, N.; Weckhuysen, B.M.; Hensen, E.J.M.; de Leeuw, N.H.; Hofmann, J.P. Enhanced Photoresponse of $\mathrm{FeS}_{2}$ Films: The Role of Marcasite-Pyrite Phase Junctions. Adv. Mater. 2016, 28, 9602-9607. [CrossRef]

51. Protopopoff, E.; Marcus, P. Poisoning of the Cathodic Hydrogen Evolution Reaction by Sulfur Chemisorbed on Platinum (110). J. Electrochem. Soc. 1988, 135, 3073-3075. [CrossRef] 
52. Chua, C.K.; Pumera, M. Susceptibility of $\mathrm{FeS}_{2}$ hydrogen evolution performance to sulfide poisoning. Electrochem. Commun. 2015, 58, 29-32. [CrossRef]

53. Zakaria, S.N.A.; Hollingsworth, N.; Islam, H.U.; Roffey, A.; Santos-Carballal, D.; Roldan, A.; Bras, W.; Sankar, G.; Hogarth, G.; Holt, K.B.; et al. Insight into the Nature of Iron Sulfide Surfaces During the Electrochemical Hydrogen Evolution and $\mathrm{CO}_{2}$ Reduction Reactions. ACS Appl. Mater. Interfaces 2018, 10, 32078-32085. [CrossRef]

54. Villalba, M.; Peron, J.; Giraud, M.; Tard, C. pH-dependence on HER electrocatalytic activity of iron sulfide pyrite nanoparticles. Electrochem. Commun. 2018, 91, 10-14. [CrossRef]

55. Giovanni, C.D.; Reyes-Carmona, Á.; Coursier, A.; Nowak, S.; Grenèche, J.M.; Lecoq, H.; Mouton, L.; Rozière, J.; Jones, D.; Peron, J.; et al. Low-Cost Nanostructured Iron Sulfide Electrocatalysts for PEM Water Electrolysis. ACS Catal. 2016, 6, 2626-2631. [CrossRef]

56. Roldan, A.; de Leeuw, N.H. Catalytic water dissociation by greigite $\mathrm{Fe}_{3} \mathrm{~S}_{4}$ surfaces: Density functional theory study. Proc. R. Soc. A 2016. [CrossRef]

57. Scanlon, D.O.; Dunnill, C.W.; Buckeridge, J.; Shevlin, S.A.; Logsdail, A.J.; Woodley, S.M.; Catlow, C.R.A.; Powell, M.J.; Palgrave, R.G.; Parkin, I.P.; et al. Band alignment of rutile and anatase $\mathrm{TiO}_{2}$. Nat. Mater. 2013, 12, 798-801. [CrossRef]

58. Xu, H.; Ouyang, S.X.; Liu, L.Q.; Reunchan, P.; Umezawa, N.; Ye, J.H. Recent advances in $\mathrm{TiO}_{2}$-based photocatalysis. J. Mater. Chem. A 2014, 2, 12642-12661. [CrossRef]

59. Wan, D.; He, Q.; Zhang, L.; Jia, Q.; Zhang, R.; Zhang, H.; Wang, B.; Wei, L. Study on pyrite FeS 2 films deposited on $\mathrm{Si}(100)$ substrate by synchrotron radiation surface x-ray diffraction method. J. Cryst. Growth 2004, 268, 222-226. [CrossRef]

60. Lee, G.; Kang, M. Physicochemical properties of core/shell structured pyrite $\mathrm{FeS}_{2} /$ anatase $\mathrm{TiO}_{2}$ composites and their photocatalytic hydrogen production performances. Curr. Appl. Phys. 2013, 13, 1482-1489. [CrossRef]

61. Kuo, T.R.; Liao, H.J.; Chen, Y.T.; Wei, C.Y.; Chang, C.C.; Chen, Y.C.; Chang, Y.H.; Lin, J.C.; Lee, Y.C.; Wen, C.Y.; et al. Extended visible to near-infrared harvesting of earth-abundant $\mathrm{FeS}_{2}-\mathrm{TiO}_{2}$ heterostructures for highly active photocatalytic hydrogen evolution. Green Chem. 2018, 20, 1640-1647. [CrossRef]

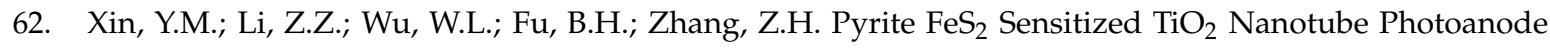
for Boosting Near-Infrared Light Photoelectrochemical Water Splitting. ACS Sustain. Chem. Eng. 2016, 4, 6659-6667. [CrossRef]

63. Meng, X.C.; Zhang, Z.S. Two dimensional graphitic materials for photoelectrocatalysis: A short review. Catal. Today 2018, 315, 2-8. [CrossRef]

64. Xu, G.R.; Hui, J.J.; Huang, T.; Chen, Y.; Lee, J.M. Platinum nanocuboids supported on reduced graphene oxide as efficient electrocatalyst for the hydrogen evolution reaction. J. Power Sources 2015, 285, 393-399. [CrossRef]

65. Wang, S.N.; Liao, L.; Shi, Z.P.; Xiao, J.J.; Gao, Q.S.; Zhang, Y.H.; Liu, B.H.; Tang, Y. $\mathrm{Mo}_{2} \mathrm{C} /$ Reduced-GrapheneOxide Nanocomposite: An Efficient Electrocatalyst for the Hydrogen Evolution Reaction. Chemelectrochem 2016, 3, 2110-2115. [CrossRef]

66. Johnson, D.W.; Dobson, B.P.; Coleman, K.S. A manufacturing perspective on graphene dispersions. Curr. Opin. Colloid Interface Sci. 2015, 20, 367-382. [CrossRef]

67. Clancy, A.J.; Bayazit, M.K.; Hodge, S.A.; Skipper, N.T.; Howard, C.A.; Shaffer, M.S.P. Charged Carbon Nanomaterials: Redox Chemistries of Fullerenes, Carbon Nanotubes, and Graphenes. Chem. Rev. 2018, 118, 7363-7408. [CrossRef]

68. Zhu, Y.; Murali, S.; Cai, W.; Li, X.; Suk, J.W.; Potts, J.R.; Ruoff, R.S. Graphene and Graphene Oxide: Synthesis, Properties, and Applications. Adv. Mater. 2010, 22, 3906-3924. [CrossRef]

69. Chen, Y.N.; Xu, S.M.; Li, Y.C.; Jacob, R.J.; Kuang, Y.D.; Liu, B.Y.; Wang, Y.L.; Pastel, G.; Salamanca-Riba, L.G.; Zachariah, M.R.; et al. $\mathrm{FeS}_{2}$ Nanoparticles Embedded in Reduced Graphene Oxide toward Robust, High-Performance Electrocatalysts. Adv. Energy Mater. 2017, 7, 1700482. [CrossRef]

70. Marcano, D.C.; Kosynkin, D.V.; Berlin, J.M.; Sinitskii, A.; Sun, Z.; Slesarev, A.; Alemany, L.B.; Lu, W.; Tour, J.M. Improved Synthesis of Graphene Oxide. ACS Nano 2010, 4, 4806-4814. [CrossRef]

71. Jiang, J.; Zhu, L.; Chen, H.; Sun, Y.; Qian, W.; Lin, H.; Han, S. Highly active and stable electrocatalysts of $\mathrm{FeS}_{2}$-reduced graphene oxide for hydrogen evolution. J. Mater. Sci. 2019, 54, 1422-1433. [CrossRef]

72. Xu, Y.; Wu, R.; Zhang, J.F.; Shi, Y.M.; Zhang, B. Anion-exchange synthesis of nanoporous FeP nanosheets as electrocatalysts for hydrogen evolution reaction. Chem. Commun. 2013, 49, 6656-6658. [CrossRef] 
73. Guo, Y.X.; Shang, C.S.; Zhang, X.Y.; Wang, E.K. Electrocatalytic hydrogen evolution using the $\mathrm{MS}_{2} @ \mathrm{MoS}_{2} / \mathrm{rGO}$ $(\mathrm{M}=\mathrm{Fe}$ or Ni) hybrid catalyst. Chem. Commun. 2016, 52, 11795-11798. [CrossRef]

74. Jiang, J.; Zhu, L.; Chen, H.; Sun, Y.; Lin, H.; Han, S. Effect of nickel-doped $\mathrm{FeS}_{2}$ nanoparticles-reduced graphene oxide electrocatalysts for efficient hydrogen evolution. J. Alloys Compd. 2019, 775, 1293-1300. [CrossRef]

75. Li, Y.; Yin, J.; Chu, C.; Sui, N.; Shi, S.; Wei, J.; Di, F.; Guo, J.; Wang, C.; Xu, W.; et al. Earth-abundant Fe $1-x$ S@Sdoped graphene oxide nano-micro composites as high-performance cathode catalysts for green solar energy utilization: Fast interfacial electron exchange. RSC Adv. 2018, 8, 4340-4347. [CrossRef]

76. Begum, A.; Sheikh, A.H.; Moula, G.; Sarkar, S. $\mathrm{Fe}_{4} \mathrm{~S}_{4}$ Cubane Type Cluster Immobilized on a Graphene Support: A High Performance $\mathrm{H}_{2}$ Evolution Catalysis in Acidic Water. Sci. Rep. 2017, 7, 16948. [CrossRef]

77. Yuhas, B.D.; Smeigh, A.L.; Samuel, A.P.S.; Shim, Y.; Bag, S.; Douvalis, A.P.; Wasielewski, M.R.; Kanatzidis, M.G. Biomimetic Multifunctional Porous Chalcogels as Solar Fuel Catalysts. J. Am. Chem. Soc. 2011, 133, 7252-7255. [CrossRef]

78. Shim, Y.; Young, R.M.; Douvalis, A.P.; Dyar, S.M.; Yuhas, B.D.; Bakas, T.; Wasielewski, M.R.; Kanatzidis, M.G. Enhanced Photochemical Hydrogen Evolution from $\mathrm{Fe}_{4} \mathrm{~S}_{4}$-Based Biomimetic Chalcogels Containing $\mathrm{M}^{2+}$ ( $\mathrm{M}=\mathrm{Pt}, \mathrm{Zn}, \mathrm{Co}, \mathrm{Ni}, \mathrm{Sn})$ Centers. J. Am. Chem. Soc. 2014, 136, 13371-13380. [CrossRef]

79. Huang, S.Y.; Sodano, D.; Leonard, T.; Luiso, S.; Fedkiw, P.S. Cobalt-Doped Iron Sulfide as an Electrocatalyst for Hydrogen Evolution. J. Electrochem. Soc. 2017, 164, F276-F282. [CrossRef]

80. Kuo, T.-R.; Chen, W.-T.; Liao, H.-J.; Yang, Y.-H.; Yen, H.-C.; Liao, T.-W.; Wen, C.-Y.; Lee, Y.-C.; Chen, C.-C.; Wang, D.-Y. Improving Hydrogen Evolution Activity of Earth-Abundant Cobalt-Doped Iron Pyrite Catalysts by Surface Modification with Phosphide. Small 2017, 13, 1603356. [CrossRef]

81. Wang, D.Y.; Gong, M.; Chou, H.L.; Pan, C.J.; Chen, H.A.; Wu, Y.P.; Lin, M.C.; Guan, M.Y.; Yang, J.; Chen, C.W.; et al. Highly Active and Stable Hybrid Catalyst of Cobalt-Doped $\mathrm{FeS}_{2}$ Nanosheets-Carbon Nanotubes for Hydrogen Evolution Reaction. J. Am. Chem. Soc. 2015, 137, 1587-1592. [CrossRef]

82. Li, Y.X.; Yin, J.; An, L.; Lu, M.; Sun, K.; Zhao, Y.Q.; Gao, D.Q.; Cheng, F.Y.; Xi, P.X. FeS $2 / \mathrm{CoS}_{2}$ Interface Nanosheets as Efficient Bifunctional Electrocatalyst for Overall Water Splitting. Small 2018, 14, 1801070. [CrossRef]

83. Wang, K.; Guo, W.L.; Yan, S.C.; Song, H.Z.; Shi, Y. Hierarchical Co-FeS $2 / \mathrm{CoS}_{2}$ heterostructures as a superior bifunctional electrocatalyst. RSC Adv. 2018, 8, 28684-28691. [CrossRef]

84. Zhao, X.; Ma, X.; Lu, Q.Q.; Li, Q.; Han, C.; Xing, Z.C.; Yang, X.R. FeS 2 -doped $\mathrm{MoS}_{2}$ nanoflower with the dominant $1 \mathrm{~T}-\mathrm{MoS}_{2}$ phase as an excellent electrocatalyst for high-performance hydrogen evolution. Electrochim. Acta 2017, 249, 72-78. [CrossRef] 